\title{
9. DIAGENETIC ALBITIZATION, ZEOLITIZATION, AND REPLACEMENT IN MIOCENE SANDSTONES, SITES 796, 797, AND 799, JAPAN SEA ${ }^{1}$
}

\author{
Sam Boggs, Jr., ${ }^{2}$ and Abbas Seyedolali ${ }^{2}$
}

\begin{abstract}
Framework grains and matrix in sandstones from ODP Sites 796, 797, and 799 have been altered to various degrees owing to chemical diagenetic processes. Petrographic and geochemical data show that albitization of plagioclase feldspars and replacement of matrix, glass shards, volcanic rock fragments, and feldspars by zeolites, carbonates, clay minerals, sulfates, and sulfides were the dominant diagenetic processes.

Feldspars in the volcanic lithic sandstones at Site 796, which were buried to shallow depths and subjected to relatively low diagenetic temperatures $\left(40^{\circ}-65^{\circ} \mathrm{C}\right)$, have not been albitized. On the other hand, zeolites have replaced many of the glass shards, and calcite has extensively replaced mud matrix and framework grains in many sandstones at this site. Most plagioclase feldspars in the volcanic lithic sandstones at Site 797 , where diagenetic temperatures may have exceeded $100^{\circ} \mathrm{C}$, have been altered to albite. In addition, zeolites, mixed-layer clay minerals, anhydrite, barite, and calcite commonly replace glass shards, volcanic rock fragments, and feldspars. Many plagioclase feldspars in the feldspathic sandstones (arkoses) at Site 799, which were subjected to diagenetic temperatures of approximately $100^{\circ} \mathrm{C}$, have also been albitized. Zeolites are absent in Site 799 sandstones, but kaolinite occurs as a cement and as a replacement mineral for matrix and feldspars. Carbonate minerals, particularly calcite, are common replacement minerals for matrix, plagioclase, orthoclase, and volcanic rock fragments at Site 799.

Because albitization has altered the original compositions of Site 797 and 799 plagioclase feldspars, these feldspars are not reliable indicators of the compositions of the parent source rocks. Total replacement of some framework grains in Site 796, 797, and 799 sandstones by zeolites or carbonates has also reduced the provenance information available from the framework grains.
\end{abstract}

\section{INTRODUCTION}

Sandstones were recovered at three sites $(796,797,799)$ during Leg 127-128 drilling in the Japan Sea during the summer of 1989 (Fig. 1). Sandstones at Site 796 in the northeast Japan Basin are volcaniclastic (volcanic lithic) sandstones that occur as thin beds, a few centimeters to $1 \mathrm{~m}$ thick, throughout a stratigraphic interval of about $350 \mathrm{~m}$. They are interbedded in clayey sediments that range in age from late Miocene to Pliocene (Fig. 2). Only the Miocene-age sandstones are discussed in this paper. Sandstones at Site 797 are also volcaniclastic sandstones of early Miocene age. These sandstones form thicker units $(<1-9 \mathrm{~m})$ that are interlayered between basaltic sills and flows in the bottom $250 \mathrm{~m}$ of the hole. Sandstones at Site 799 are feldspathic sandstones (arkoses) of early Miocene age that range in thickness from $<1 \mathrm{~m}$ to $5 \mathrm{~m}$. These sandstones are interbedded in claystones and siliceous claystones in the basal $65 \mathrm{~m}$ of the hole. The sandstones at all of these sites typically display graded bedding. They are interpreted to be the deposits of sediment gravity flows (Shipboard Scientific Party, 1990a, 1990b, 1990c). Their stratigraphic and sedimentologic characteristics, framework compositions, and provenance are described elsewhere (Boggs and Seyedolali, this volume).

The framework constituents and matrix components of Leg 127 and 128 sandstones show various degrees of postdepositional diagenetic alteration. The present paper focuses on the characteristics of Site 796, 797, and 799 sandstones that are the result mainly of chemical diagenetic processes. The mineralogical and chemical compositions of sandstone samples were studied by using petrographic, $\mathrm{X}$-ray diffraction, electron microprobe, and backscattered electron microscopy methods to evaluate diagenetic alteration. Diagenetic effects are particularly prominent in Site 797 sandstones that are associated with basaltic intrusions (sills), but diagenesis has also affected the sandstones at Sites 796 and 799. Alteration of sandstone framework grains during diagenesis can adversely influence provenance interpretation (Helmold, 1985). Therefore, we were particu-

\footnotetext{
${ }^{1}$ Pisciotto, K. A., Ingle, J. C., Jr., von Breymann, M. T., Barron, J., et al., 1992. Proc. ODP, Sci. Results, 127/128, Pt. 1: College Station, TX (Ocean Drilling Program). U.S.A
}

larly interested in evaluating possible loss of provenance information owing to destruction of detrital framework constituents or alteration of these constituents beyond recognition. Diagenetic changes also provide insight into the burial history of the sediments and the paragenetic sequences of authigenic minerals that formed in these sandstones during burial.

\section{METHODS}

Samples of sandstones from Sites 796 and 797 were obtained by the senior author during shipboard sampling on Leg 127. Subsequently, sandstone samples from Site 799 were furnished by the Ocean Drilling Program curator, Texas A\&M University. Fourteen samples from Site 796, 43 samples from Site 797, and 10 samples from Site 799 were analyzed petrographically to study diagenetic textures. More than 650 feldspar grains in 27 polished samples were analyzed with a CAMECA SX 50 electron probe microanalyzer to evaluate the effects of albitization on feldspar composition. Backscattered electron microscopy was also used to study the effects of albitization. One hundred analyses of authigenic zeolites, mainly from Sites 796 and 797, were carried out with the electron microprobe to aid in zeolite identification. We also analyzed representative bulk samples from the three sites by X-ray diffraction methods; however, the X-ray patterns proved to be inadequate for identifying clay minerals and zeolites. The core depths of the samples analyzed and the kinds of analyses performed are shown in the Appendix. The framework compositions of the samples are discussed elsewhere (Boggs and Seyedolali, this volume).

\section{PRINCIPAL DIAGENETIC PROCESSES AND EFFECTS}

\section{General Statement}

Sandstones from Sites 796 and 797 are volcaniclastic sandstones that contain high proportions of volcanic rock fragments, glass, and plagioclase feldspars. Site 797 sandstones also contain moderate amounts of sanidine and quartz. By contrast, Site 799 sandstones contain only minor amounts of volcanic detritus. Instead, they are composed 


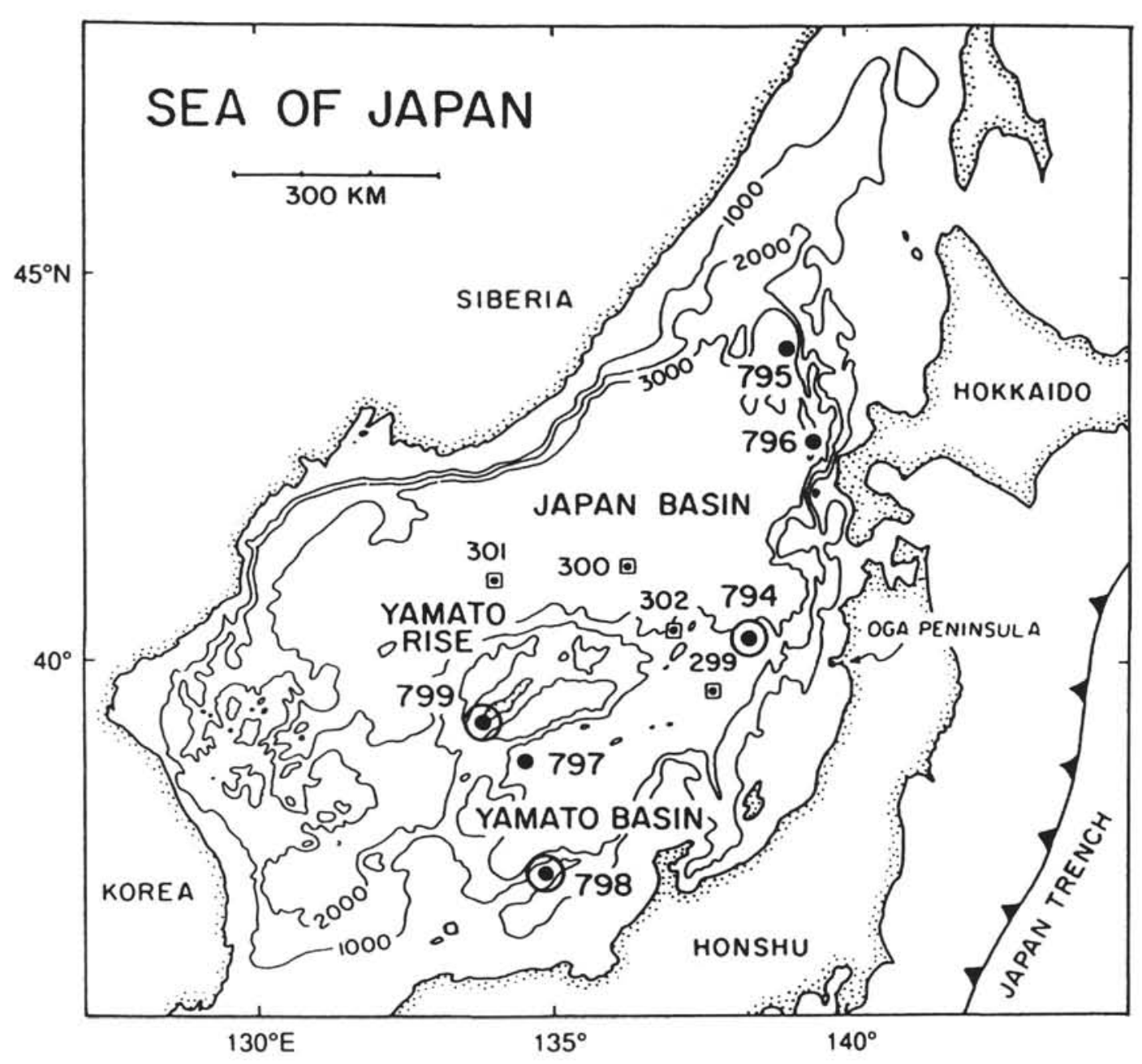

Figure 1. Location map of the Japan Sea showing drill sites for Leg 127 (solid dots) and Leg 128 (circled dots). Sites 796, 797, and 798 are the focus of this paper. (From Proceedings of the Ocean Drilling Program, Initial Reports, Vol. 128, Fig. 2, p. 7.)

mainly of quartz, orthoclase feldspars, plagioclase feldspars, and plutonic (granitic) rock fragments, which indicate derivation mainly from granitic plutonic rocks. Most Site 796 and 799 sandstones contain abundant mud matrix, and many are mud supported; that is, sand-size grains do not touch and do not form a supporting framework. Site 797 sandstones typically contain much less mud matrix, and most of these sandstones have a grain-supported fabric.

Much of the mud matrix in some Site 796 and 799 sandstones has been replaced by carbonate minerals. The matrix in Site 797 sandstones is less affected by carbonate replacement; however, the matrix shows extensive alteration to mixed-layer clay minerals and chlorite. The framework constituents of Site 796, 797, and 799 sandstones have also been replaced to various degrees by carbonates, zeolites, clay minerals, anhydrite, barite, pyrite, hematite, and microquartz (Site 797 only). Volcanic rock fragments, glass, and plagioclase feldspars have been particularly affected by replacement processes. In addition, extensive albitization of plagioclase feldspars has occurred in Site 797 and 799 sandstones. Albitization has affected the chemical composition of many of the plagioclase feldspars so severely that their chemical compositions cannot be used as an indicator of parent-rock composition. Cementation of Site 796, 797, and 799 sandstones has been relatively minor. Few Site 796 sandstones contain cements of any kind except very minor chlorite cement that fill molds created by dissolution of glass shards (Fig. 3).
Some Site 799 sandstones contain carbonate or kaolinite cements (Fig. 4), and Site 797 sandstones contain minor amounts of clay mineral (Fig. 5), zeolite, or microquartz (chert) cements. Minor authigenic silica overgrowths on quartz grains (Fig. 6) and albite overgrowths on plagioclase feldspars are also present in some Site 797 sandstones.

Physical compaction effects in Leg 127 and 128 sandstones are minor. Site 796 and 799 sandstones show little evidence of compaction other than bending of mica flakes around more rigid framework grains. The effects of compaction are somewhat more pronounced in Site 797 sandstones. In addition to bent mica flakes, some malleable grains such as lithic fragments have been squeezed to form pseudomatrix. Also, tangential contacts between grains are scarce (most are long contacts), and the average number of contacts per grains (contacts between one grain and other grains) exceeds two. Both of these factors indicate moderate compaction (Taylor, 1950).

The dominant diagenetic changes in Leg 127 and 128 sandstones have been brought about by albitization of plagioclase feldspars, replacement of glass by zeolites, and replacement of volcanic rock fragments, glass, and feldspars by carbonates and clay minerals. Some of these diagenetic processes have completely destroyed original framework grains. The remainder of this paper focuses on these important diagenetic changes. 


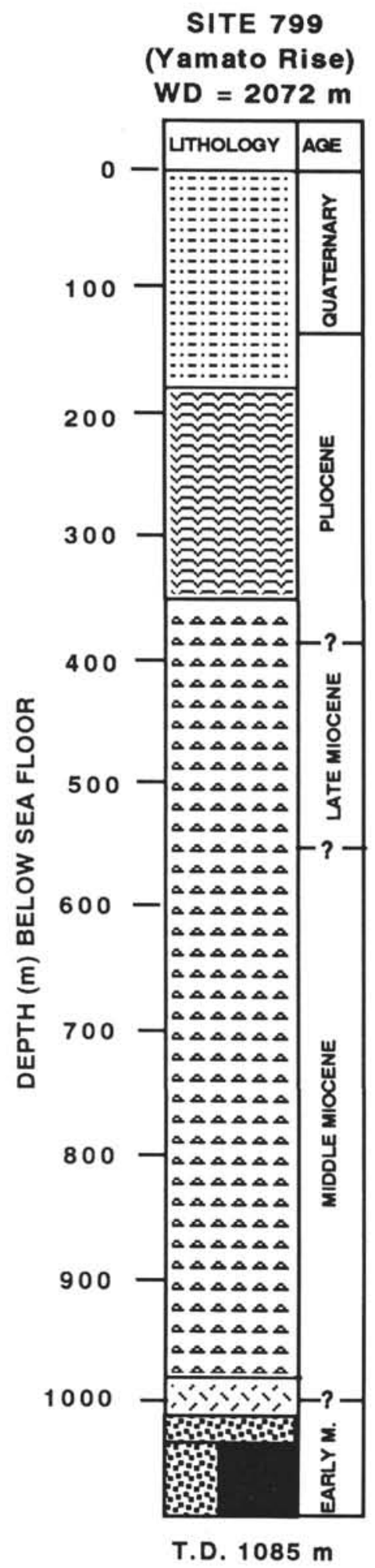

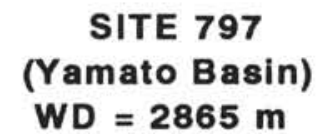

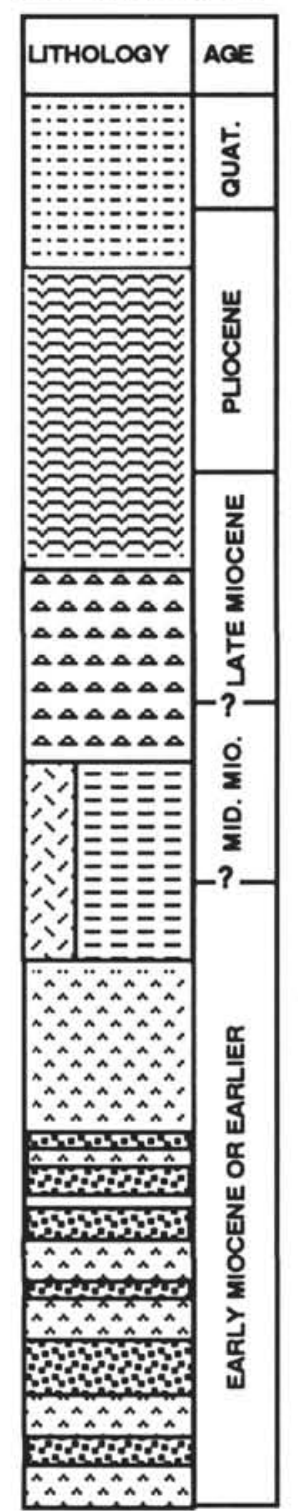

T.D. $903 \mathrm{~m}$

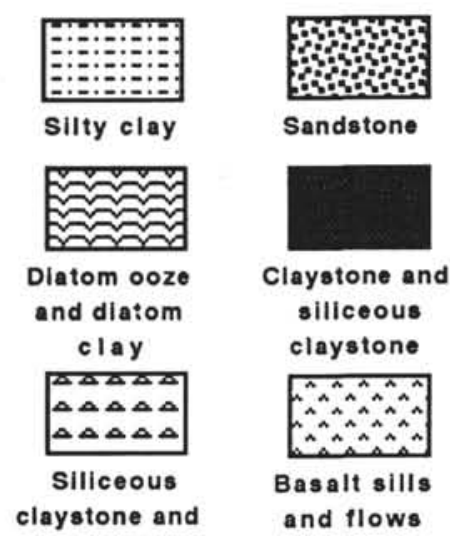

porcellanite

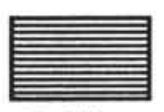

Pebbly

claystone

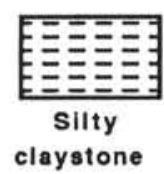

SITE 796

(Japan Basin)

WD $=2571 \mathrm{~m}$

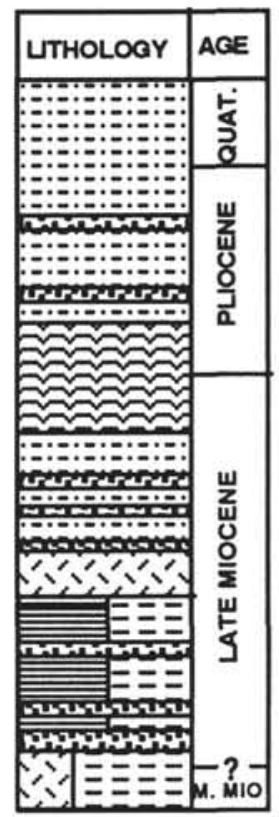

T.D. $465 \mathrm{~m}$

Figure 2. Generalized lithology of Miocene-Quaternary sediments at Sites 796 (northeastern Japan Basin), 797 (Yamato Basin), and 799 (Yamato Rise) in the Japan Sea. 


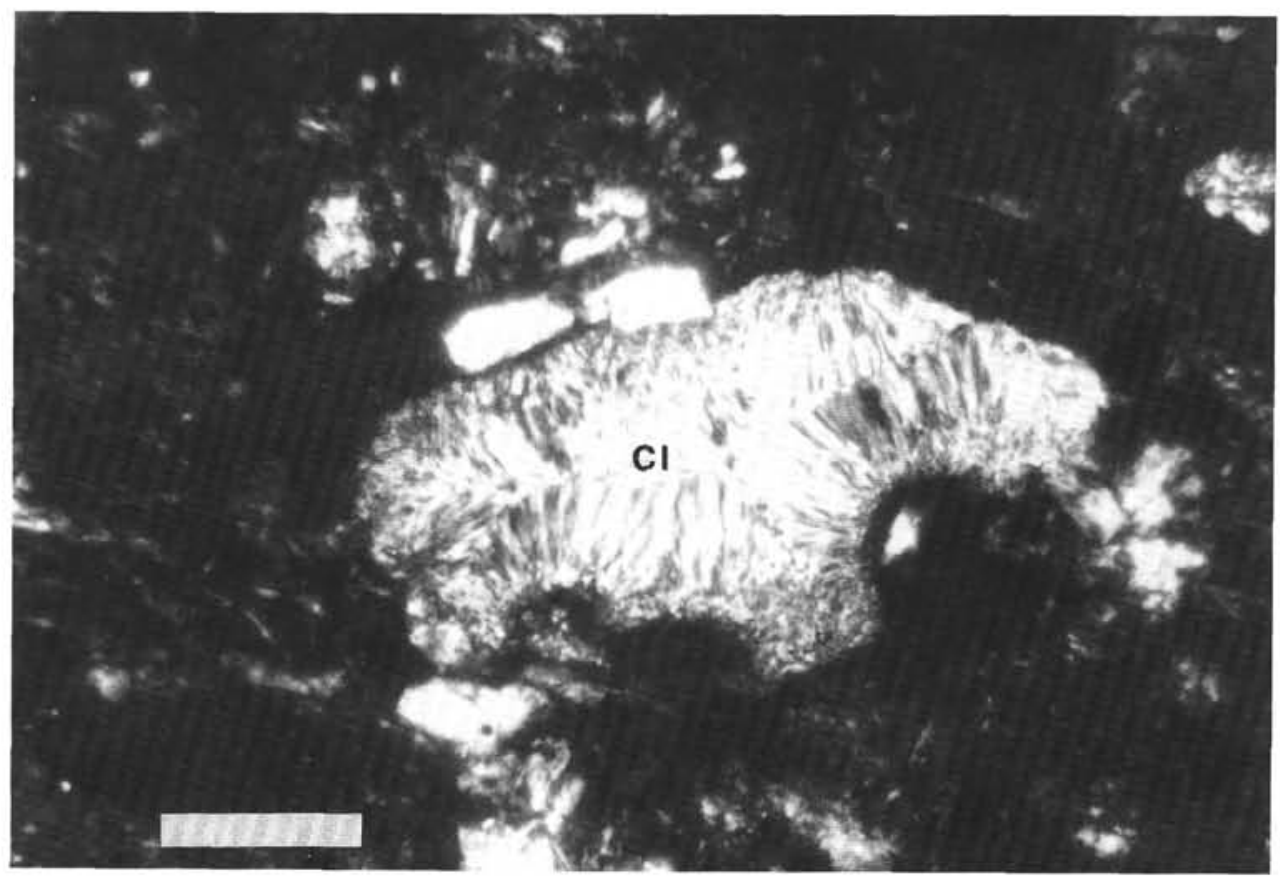

Figure 3. Chlorite cement $(\mathrm{Cl})$ in a solution cavity formed by dissolution of a glass shard. Core photograph 127-796B-1 IR, $\sim 253$ mbsf. Crossed nicols. Scale bar $=0.1 \mathrm{~mm}$.

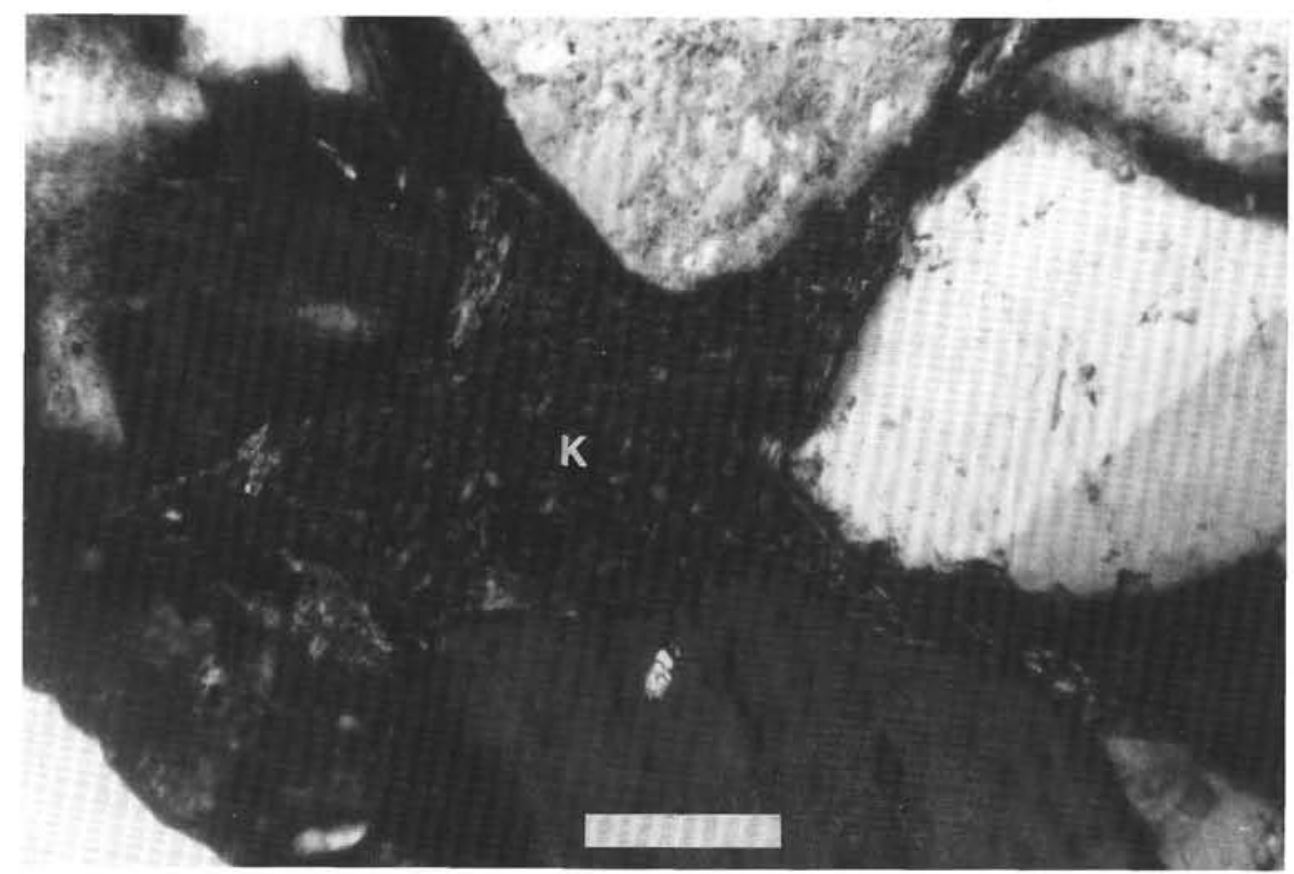

Figure 4. Kaolinite $(\mathrm{K})$ that forms a cement (and possibly replaces matrix) among feldspar grains. Core photograph 128-799B-61R, $\sim 1023$ mbsf. Crossed nicols. Scale bar $=0.1 \mathrm{~mm}$. 


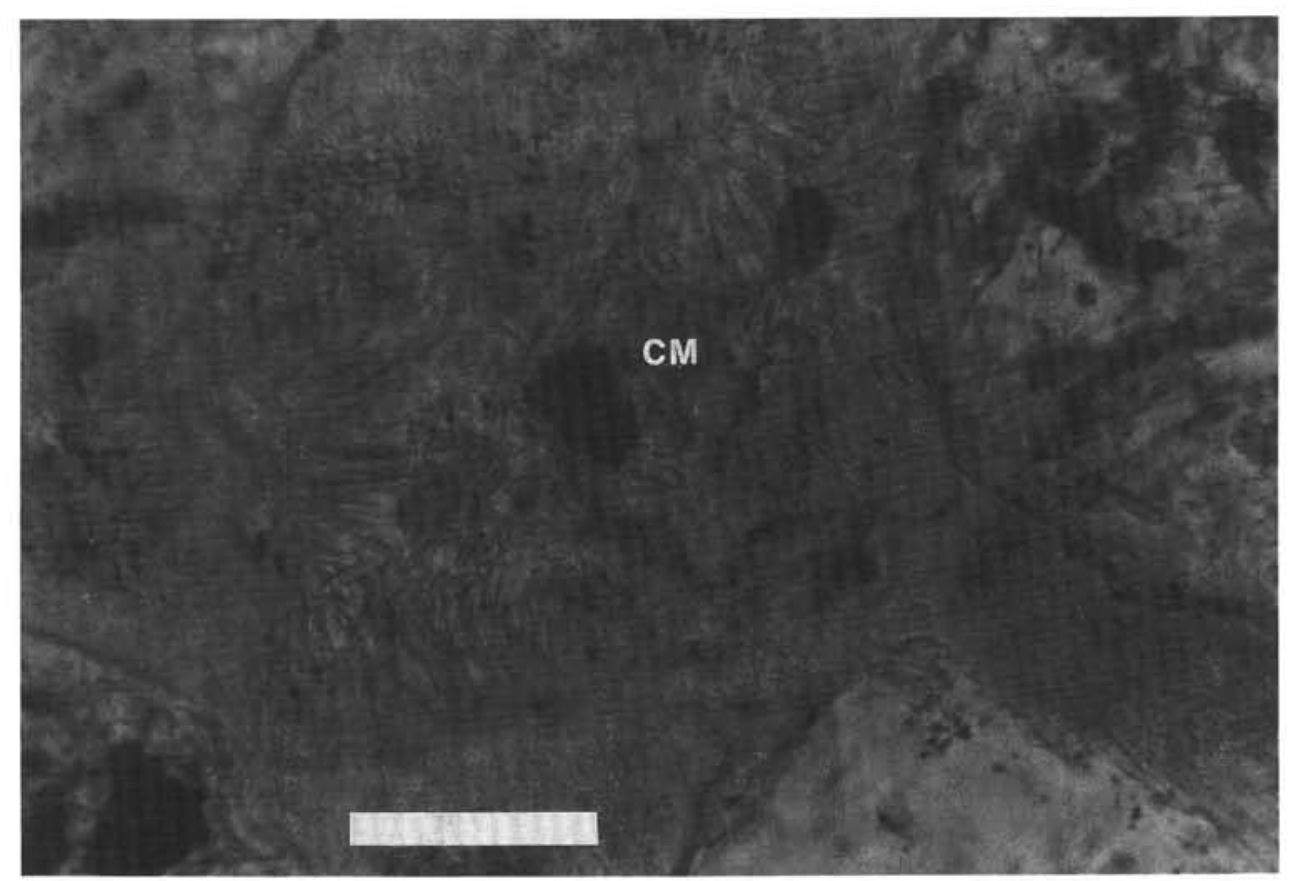

Figure 5. Fibrous, smectite (?) clay-mineral cement (CM) that fills interstitial space among rock fragments and quartz. The black patches within the cement are authigenic pyrite. Core photograph $127-797 \mathrm{C}-37 \mathrm{R}, \sim 822 \mathrm{mbsf}$. Plane-polarized light. Scale bar $=0.05 \mathrm{~mm}$.

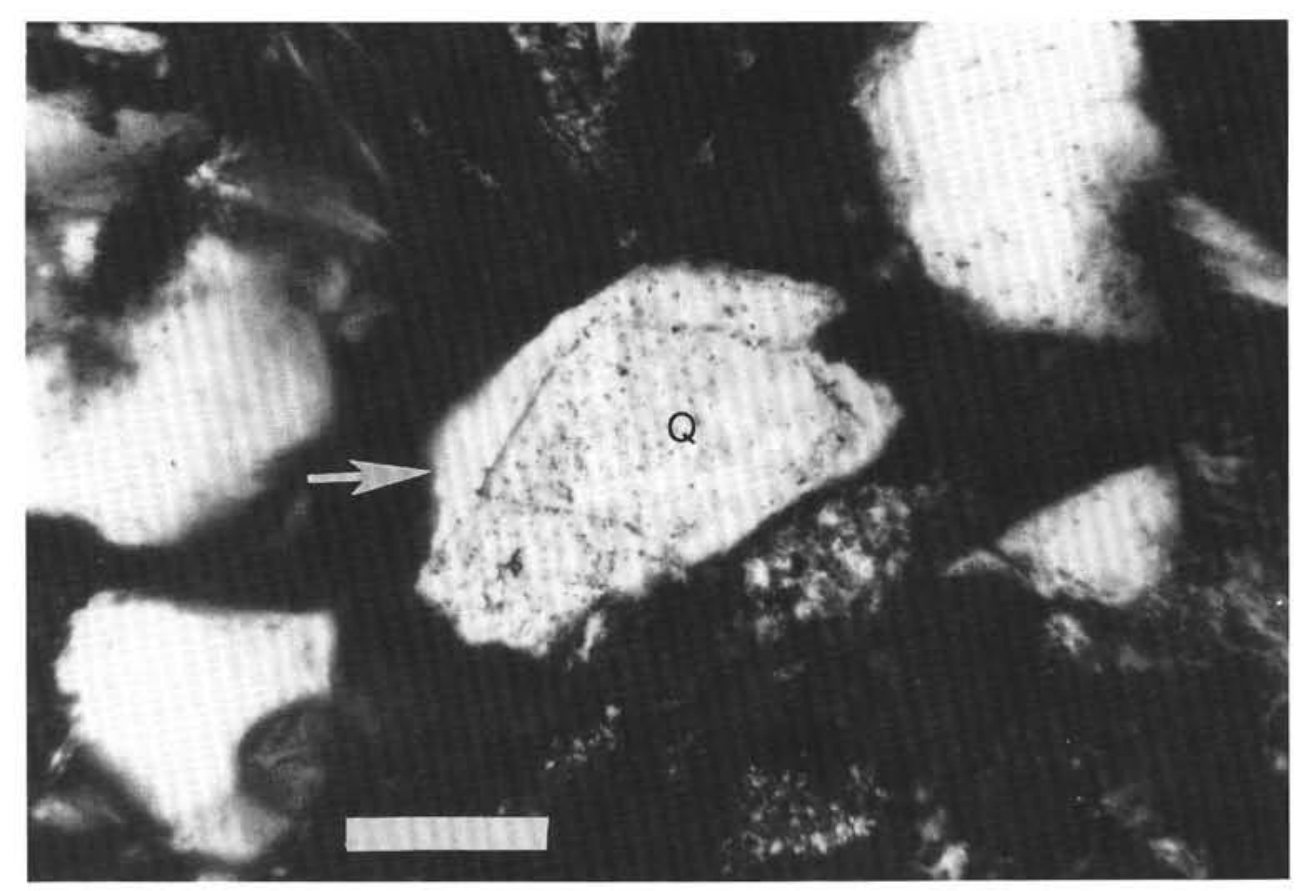

Figure 6. Detrital quartz grain (Q) with a silica overgrowth (arrow). Core photograph 127-797C-22R, 690 mbsf. Crossed nicols. Scale bar $=0.1 \mathrm{~mm}$. 


\section{Albitization of feldspars}

Albitization of feldspars is a diagenetic process that involves replacement of calcic plagioclase or K-feldspar by sodic plagioclase (albite). Albitization of feldspars is a very common diagenetic process that has been reported by many investigators, and which can result in substantial loss of important provenance information owing to changes in original feldspar compositions (e.g., Milliken, 1988). Albitization is reported by some authors to occur at temperatures on the order of $100^{\circ}-150^{\circ} \mathrm{C}$ (Milliken et al., 1981; Boles, 1982; Surdam et al., 1989). On the other hand, albitization has also been reported to take place at lower temperatures on the order of $60^{\circ}-100^{\circ} \mathrm{C}$ (Morad et al., 1990; Aagaard et al., 1990; Saigal et al., 1988). Albitization may occur by direct replacement of feldspars by albite, or through intermediate stages that involve initial replacement of feldspars by calcite, anhydrite, zeolites, or other minerals, followed by replacement of these minerals by albite (Walker, 1984). Albitization may also occur by partial dissolution of detrital feldspars, followed by precipitation of albite in dissolution voids (Milliken, 1989). Albitization is revealed by the presence of distinctive textures in feldspars such as the "chessboard" texture reported by Walker (1984) or blocky to tabular sector extinction patterns (Gold, 1987), and by albite overgrowths on plagioclase grains (Milliken, 1989). Distinctive patterns of albitization may also be revealed by backscattered electron microscopy (e.g., Gold, 1987; Morad et al., 1990). Finally, exceptionally high abundances of albite in a sandstone generally indicates albitization, although albite can be detrital. Detrital albites can be derived by weathering of metamorphic source rocks (Deer et al., 1966) or igneous rocks that have been altered by hydrothermal and postmagmatic albite replacement of feldspars (AlDahan et al., 1987).

The chemical compositions of 650 feldspar grains from 27 samples were determined with an electron probe microanalyzer. The results of these analyses are displayed in Figures 7, 8, and 12. These ternary composition plots show composition in terms of Or (potassium), Ab (sodium), An (calcium) end members. Site 796 sandstones (Fig. 7) contain few potassium feldspars. Plagioclase feldspars are abundant and encompass a wide range of compositions from anorthite $\left(\mathrm{Or}_{0.4} \mathrm{Ab}_{7.9} \mathrm{An}_{91.7}\right)$ to oligoclase $\left(\mathrm{Or}_{4.7} \mathrm{Ab}_{84.6} \mathrm{An}_{10.7}\right)$. These plagioclase compositions indicate derivation from volcanic source rocks that mainly range in composition from basic to intermediate (Trevena and Nash, 1981). None of the feldspars fall in the albite field, which shows that Site 796 feldspars have not been albitized. The estimated temperature at Site 796 between about 250 and $425 \mathrm{~m}$ depth, the depth range of Site 796 Miocene sandstones, is about $40^{\circ}-65^{\circ} \mathrm{C}$ (Shipboard Scientific Party, 1990a). These temperatures are below the range at which albitization is likely to occur (see discussion below).

Figure 8 shows, by contrast, that the compositions of large numbers of Site 797 feldspars fall in the albite field. For example, the compositions of more than 100 feldspars overlap in the extreme corner of this field. The compositions of many of these feldspars are nearly pure albite, but composition ranges from $\mathrm{Or}_{0.2} \mathrm{Ab}_{65.2} \mathrm{An}_{34.6}$ to $\mathrm{Or}_{0.5} \mathrm{Ab}_{99.5} \mathrm{An}_{0}$. Petrographic study indicates that these feldspars are plagioclase (Boggs and Seyedolali, this volume) and that they include both twinned and untwinned plagioclase. About $60 \%$ of Site 797 plagioclase feldspars are untwinned, which may in itself be evidence of albitization (Kastner and Siever, 1979; Morad et al., 1990). On the other hand, we found that polysynthetic twinning was preserved in many albitized grains. In addition to these compositional data, we see considerable textural evidence of albitization by both petrographic study and backscattered electron microscopy. This evidence includes plagioclase grains that display a kind of reticulate texture (Fig. 9) or blocky extinction pattern that arises from incomplete albitization, as well as albite overgrowths on plagioclase grains. Gold (1987) suggests that blocky or tabular extinction patterns in detrital plagioclase grains result from incipient dissolution along cleavage planes, followed by precipitation of optically clear albite within the dissolution pores. This texture in Site 797 plagioclase grains appears to be

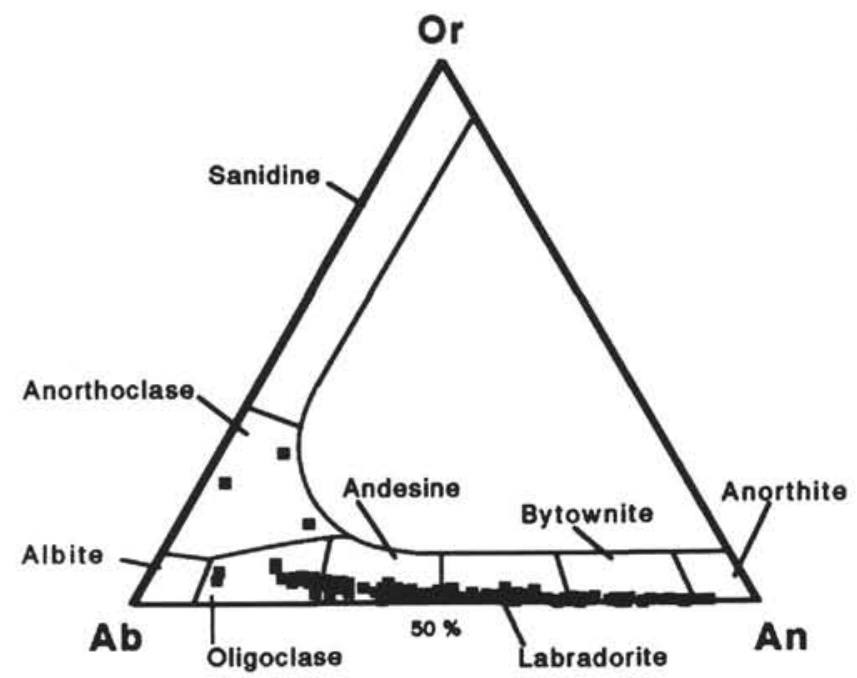

Figure 7. Chemical composition of feldspars from Site 796 displayed on a standard $\operatorname{Or}(\mathrm{K}), \mathrm{Ab}(\mathrm{Na}), \mathrm{An}(\mathrm{Ca})$ diagram. The absence of albitic feldspars suggests that no diagenetic albitization of feldspars has occurred in Site 796 sandstones. (Total grains analyzed, 232.)

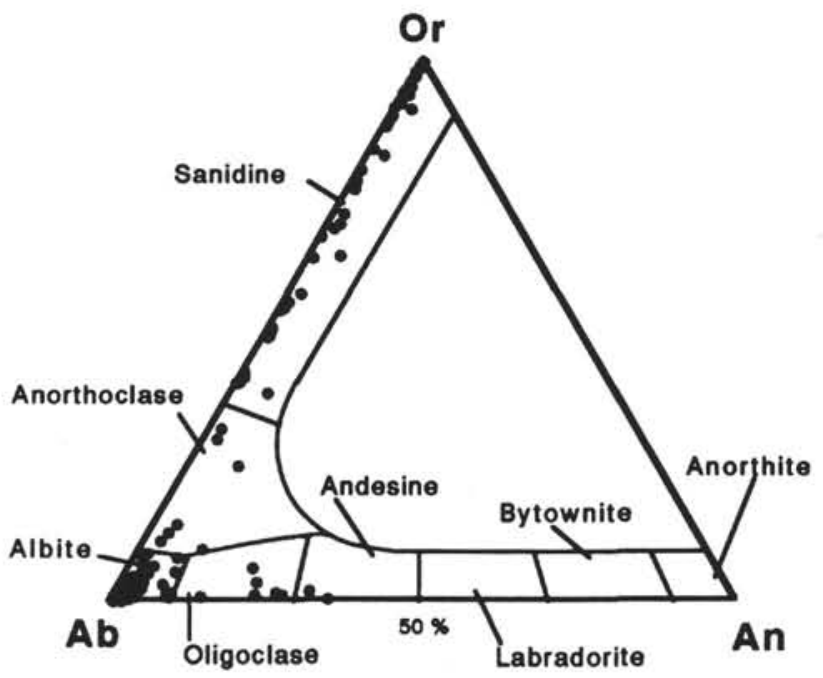

Figure 8. Chemical composition of feldspars from Site 797. The high concentration of feldspars in the albite composition field suggests extensive diagenetic albitization of Site 797 plagioclase feldspars. Potassium feldspars are not affected by albitization. (Total grains analyzed, 188.)

emphasized by plucking of parts of the feldspar grains during grinding and polishing of thin sections (e.g., Fig. 9). In addition, a few feldspar grains composed of multiple albite crystals (Fig. 10) are present in Site 797 sandstones. We have not seen this kind of texture in unalbitized feldspars. On the other hand, some of these polycrystalline albites may originally have been volcanic rock fragments, or zeolites that have been dehydrated and altered to albite, rather than feldspars. Backscattered electron microscopy is an especially useful tool for studying albitization (e.g., Gold, 1987; Morad et al., 1990). Albitized (sodic) and unalbitized (calcic) portions of feldspars show up quite clearly in backscattered photographs owing to atomic number contrast between calcium and sodium. Figure 11 provides an example. The darker parts of this grain are strongly albitized areas; the lighter parts are less sodium rich. 


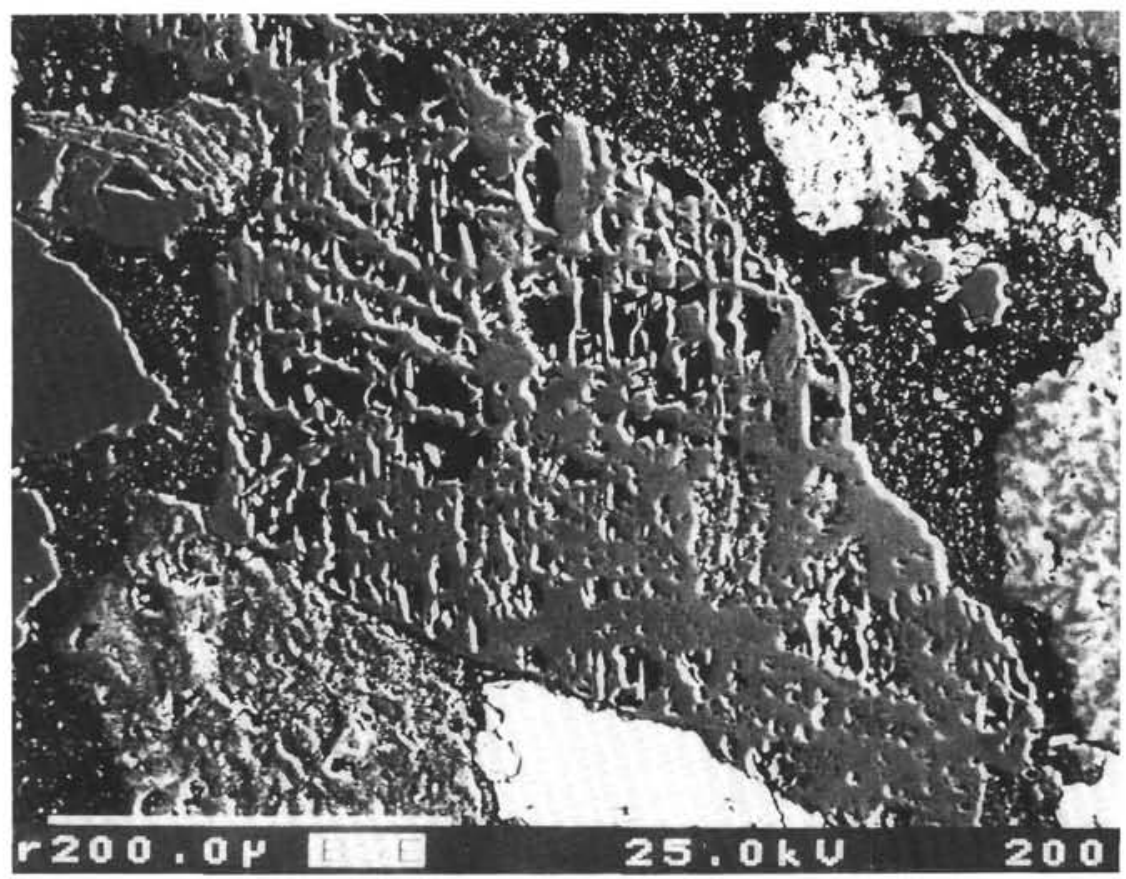

Figure 9. Plagioclase feldspar grain (center of photograph) highly altered owing to albitization. Differential albitization or incipient solution may have been accentuated by plucking of parts of the grain (black areas) during grinding and polishing of the thin section. Photographed by backscattered electrons. Site 797 , Core $37 \mathrm{R}, \sim 818 \mathrm{mbsf}$. Scale bar $=200 \mu \mathrm{m}$.

Most of the plagioclase feldspars in Site 797 sandstones have been albitized. By contrast, the potassium feldspars in Site 797 sandstones, which are mainly sanidine, appear to be unaffected or only slightly affected by albitization. Morad et al. (1990) report similar patterns of albitized plagioclase and unalbitized or very slightly albitized Kfeldspars in Triassic rocks of the Norwegian North Sea. They suggest that temperature is an important factor that accounts for the difference in albitization of plagioclase and K-feldspars. In the Norwegian Triassic rocks, albitization of plagioclase occurred at temperatures of $75^{\circ}-100^{\circ} \mathrm{C}$. Morad et al. (1990) suggest that albitization of K-feldspars would increase at greater burial depths and higher temperatures $\left(>\sim 125^{\circ} \mathrm{C}\right)$. Also, Aagaard et al. (1990) indicate that albitization of $\mathrm{K}$-feldspar is a slow process and is more sensitive to potassium removal than to sodium supply. Extrapolated temperatures in Site 797 sandstones, all of which are present near the bottom of the hole (Fig. 2), are about $70^{\circ}-75^{\circ} \mathrm{C}$ (Shipboard Scientific Party, 1990b). At the time of albitization of Site 797 sandstones, however, temperatures were likely much higher owing to intrusion of basaltic sills into the sandstones. Nonetheless, the weak albitization of K-feldspars suggests that temperatures probably did not exceed $\sim 125^{\circ} \mathrm{C}$.

Some of the sodium required for albitization of plagioclase feldspars in Site 797 sandstones was probably supplied by saline pore waters. The sodium content of Site 797 pore waters at about $525 \mathrm{mbsf}$ is approximately $400 \mathrm{mmol} / \mathrm{L}$ and salinity is about $32 \mathrm{~g} / \mathrm{kg}$ (Shipboard Scientific Party, 1990b; data for pore waters near the bottom of the hole are not available.) Another process that could supply sodium may have been chloritization of smectites in interbedded shales, as suggested by Morad et al. (1990). Also, sodium may have been released from altered basaltic sills (Shipboard Scientific Party, 1990b) that intrude Site 797 sandstones. Sodium is a very mobile element, and may have easily migrated into the sandstones from adjacent sills. Calcium released by the albitization process may have increased the calcium content of pore waters. The calcium content of pore waters at $525 \mathrm{mbsf}$ is $38.3 \mathrm{mmol} / \mathrm{L}$ compared to $7.6 \mathrm{mmol} / \mathrm{L}$ at $3 \mathrm{mbsf}$; Shipboard Scientific Party, 1990b. Some calcium reprecipitated as calcite (or dolomite), anhydrite, and barite that replace framework grains and matrix in some Site 797 sandstones.

Two hundred and thirty feldspar grains from Site 799 samples were analyzed by electron microprobe. Compositional data are shown in Figure 12. The compositional range of the plagioclase feldspars is $\mathrm{Or}_{1.2} \mathrm{Ab}_{63.8} \mathrm{An}_{35.0}$ to $\mathrm{Or}_{0.2} \mathrm{Ab}_{99.7} \mathrm{An}_{0.1}$. These data, as well as petrographic observation, suggest that many of the plagioclase grains in Site 799 sandstones have also been albitized. The K-feldspars, which are mainly orthoclase, appear to be largely unaffected by albitization. Some petrographic evidence of albitization of Site 799 plagioclase is shown in Figures 13 and 14. A few Site 799 feldspars studied by backscattered electron microscopy also provides evidence of albitization similar to that illustrated in Figure 11. The carbonates and kaolinite that occur in Site 799 sandstones may be by-products of albitization (Boles, 1982).

The temperature extrapolated to the bottom of Hole 799 at $1046 \mathrm{mbsf}$ is almost $100^{\circ} \mathrm{C}$ (Shipboard Scientific Party, 1990c). This temperature is within the range at which albitization of plagioclase could be expected, assuming that permeability is adequate to promote fluid flow. As mentioned, we cannot exclude the possibility that some of the albite grains in Site 799 (and Site 797) sandstones are detrital plagioclase that were derived by weathering of metamorphic rocks or igneous rocks that contained albite formed by hydrothermal and postmagmatic replacement of feldspars (AIDahan et al., 1987).

\section{Zeolitization}

Zeolite minerals are structurally similar to feldspars, but their structure is much more open and they contain considerable water. Volcaniclastic sediments typically undergo alteration to zeolites during diagenesis. Plagioclase feldspars, volcanic glass, and volcanic rock fragments are particularly susceptible to zeolite alteration. Clay minerals and biogenic silica may also be involved in some reactions. Zeolitization can take place over a broad range of temperatures from about $10^{\circ}$ to $>200^{\circ} \mathrm{C}$, with the upper limit of pressure and temperature 


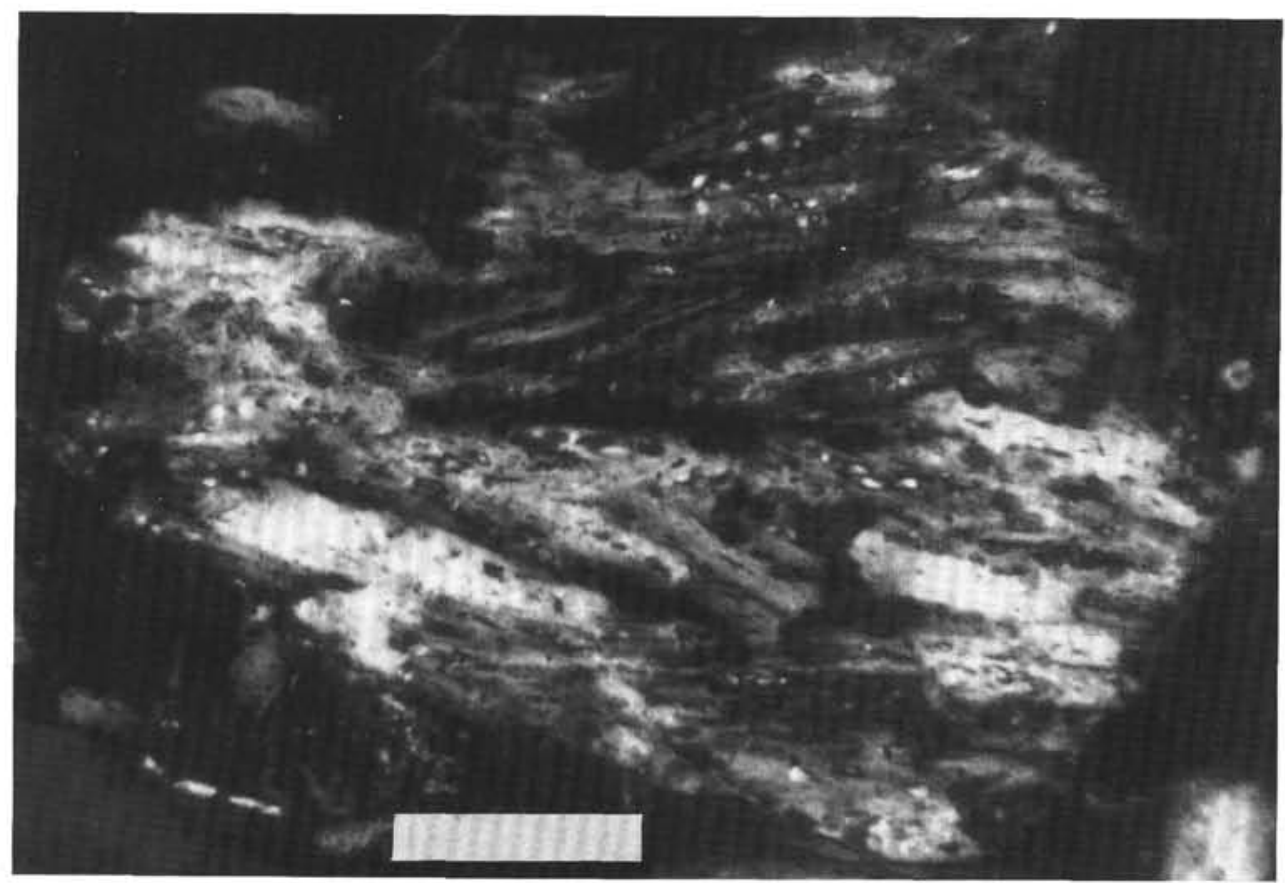

Figure 10. Plagioclase grain composed of multiple, roughly oriented albite laths. Core photograph 127-797C-37R, $\sim 822$ mbsf. Crossed nicols. Scale bar $=0.05 \mathrm{~mm}$.

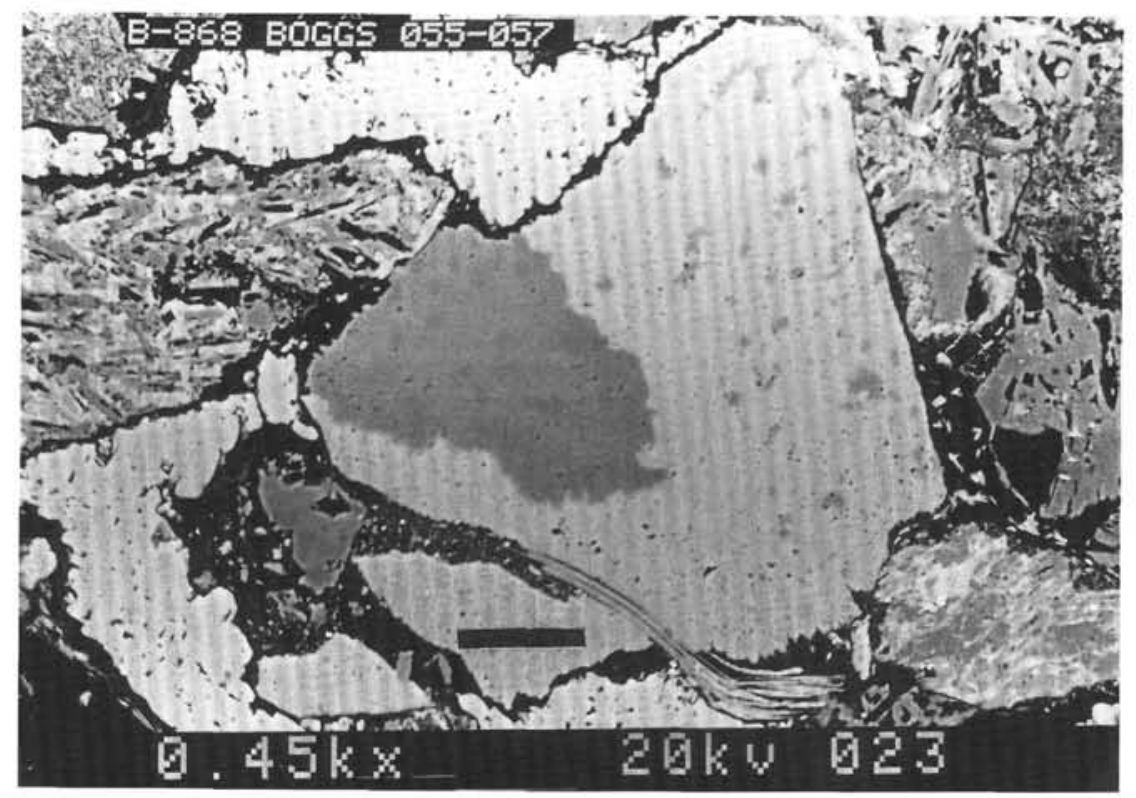

Figure 11. Partial albitization of a plagioclase grain (center of photograph) as revealed by backscattered electron microscopy. The dark patches are highly albitized areas; the lighter areas are less sodium rich. Core photograph 127-797C-34R, $\sim 698 \mathrm{mbsf}$. Scale bar $=30 \mu \mathrm{m}$.

being about $3 \mathrm{~kb}$ pressure and $300^{\circ} \mathrm{C}$ (Surdam and Boles, 1979). The diagenesis of zeolites can involve both hydration and dehydration reactions. Hydration occurs during the early stages of diagenesis when plagioclase and glass are altered to zeolites. Dehydration occurs during later diagenesis at higher temperatures, and may result in conversion of one zeolite to another or to another mineral such as albite.
Zeolites are common minerals in the volcaniclastic sandstones of Sites 796 and 797, but they are not present in the feldspathic sandstones at Site 799. Typically, they replace glass shards or plagioclase grains. Less commonly, the zeolites form cements.

At Site 796, zeolites occur in Miocene sandstone beds at depths ranging between about 250 and $425 \mathrm{~m}$ (Fig. 2) and at temperatures ranging from about $40^{\circ}$ to $65^{\circ} \mathrm{C}$. Petrographic analysis shows that 


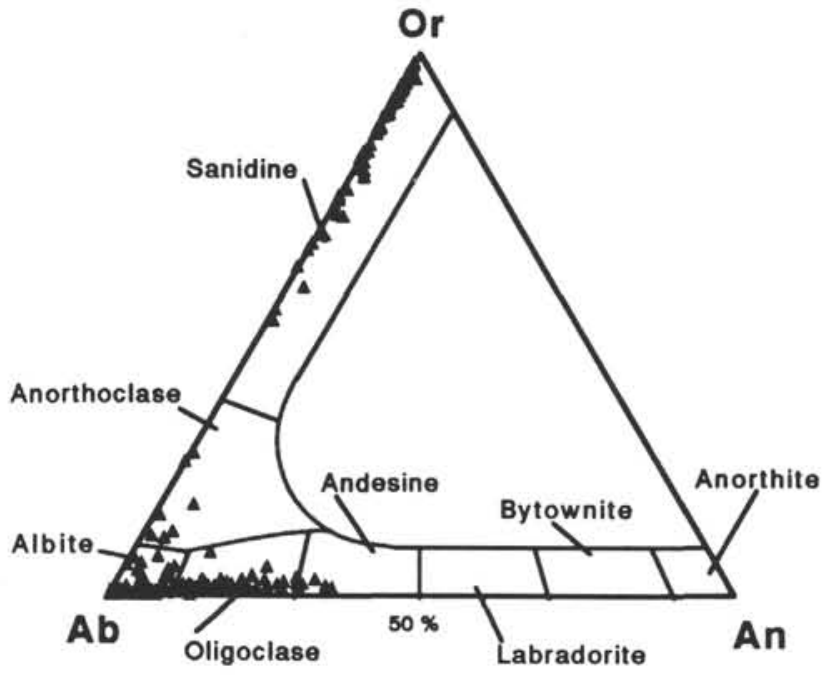

Figure 12. Chemical composition of feldspars from Site 799 sandstones. Most of the plagioclase feldspars are very sodium rich, suggesting diagenetic albitization. The potassium feldspars show no evidence of sodium enrichment. (Total grains analyzed, 230.)

most of these sandstones contain about $1 \%-4 \%$ zeolites; however, a few samples contain as much as $10 \%$ zeolites. Zeolites are particularly abundant at a depth of about $310-320$ mbsf, in sandstones that lie almost immediately above a thick volcanic tuff unit. Most of the zeolites in Site 796 sandstones replace glass shards (Fig. 15), many of which are in incipient stages of replacement. About 50 zeolitized glass shards from a range of depths in Hole 796 (Appendix) were analyzed with the electron probe microanalyzer to determine composition of the zeolites. All of the zeolites have $\mathrm{Si} / \mathrm{Al}+\mathrm{Fe}$ ratios that range between 4.0 and 5.0 (Fig. 16), and all show strong sodium enrichment with respect to both potassium and calcium. These zeolites are identified as alkali clinoptilolites. Clinoptilolites are known to be common in deep-sea sediments, and alkali clinoptilolites have been reported by Ogihara and Iijima (1989) from silicic vitric tuffs in Cretaceous marine strata from boreholes located $35 \mathrm{~km}$ offshore from the east coast of northeastern Honshu, Japan. The formation of clinoptilolite in Site 796 sandstones at temperatures of $20^{\circ}-65^{\circ} \mathrm{C}$ is consistent with the stability field for alkali clinoptilolite reported by Iijima (1978).

Zeolites are also recognized petrographically in many of the sandstones from Site 797. The content of zeolites ranges from about $3 \%$ to more than $10 \%$. The distribution of percentages is erratic and does not show a definite trend with increasing depth. The zeolites occur mainly as a replacement of volcanic glass (Fig. 17), but they may also replace plagioclase feldspars (Fig. 18) and K-feldspars. Sixty zeolitized grains from 797 sandstones were analyzed with the electron probe microanalyzer to determine chemical composition. The distribution of $\mathrm{Si} / \mathrm{Al}+\mathrm{Fe}$ ratios in these zeolites is shown in Fig. 16. The ratios fall mainly within the range of 2.0 to 3.0. Most of the zeolites are enriched in sodium with respect to potassium and calcium $(\mathrm{Na}>\mathrm{K}>\mathrm{Ca})$, although a few are enriched in potassium $(\mathrm{K}>\mathrm{Na}>\mathrm{Ca})$. On the basis of the $\mathrm{Si} / \mathrm{Al}+\mathrm{Fe}$ ratios and chemical compositions, we believe that most of the zeolites in Site 797 sandstones are analcime $(\mathrm{Si} / \mathrm{Al}+\mathrm{Fe}$ ratio $1.7-2.9)$, although some phillipsite ( $\mathrm{Si} / \mathrm{Al}+\mathrm{Fe}$ ratio $1.3-3.4)$, heulandite $(\mathrm{Si} / \mathrm{AI}+\mathrm{Fe}$ ratio $2.9-4.0)$, and clinoptilolite ( $\mathrm{Si} / \mathrm{AI}+\mathrm{Fe}$ ratio $4.0-5.1$ ) may also be present. See Hay (1981) for discussion of $\mathrm{Si} / \mathrm{Al}+\mathrm{Fe}$ ratios in zeolites.

The zeolites that we observe do not show the typical trapezohedral shape of analcime. Instead, they form lath-shaped crystals or stellate clusters of crystals (Fig. 19). They commonly show very low birefringence or they are isotropic. According to Nesse (1991, p. 291), analcime is commonly weakly birefringent $(b=0.001)$ and may display first-order interference colors. Analcime was probably derived from a precursor zeolite or zeolites, and thus forms pseudomorphs after these zeolites. Surdam (1981) suggests that analcime does not form directly from the alteration of glass. Instead, clinoptilolite, heulandite, or phillipsite are altered to analcime. Analcime pseudomorphs after prismatic clinoptilolite have been reported by Sheppard and Gude (1973), and Boles (1981) describes lath-shaped analcime pseudomorphs after heulandite.

We do not see any specific pattern of zonation in these zeolites over the roughly $200-\mathrm{m}$ interval in which they occur. They appear to fall mainly in Iijima's zeolite zone 3 (Iijima, 1978), which is the zone characterized by transformation of clinoptilolite to analcime (Fig. 20). Extrapolated temperatures near the bottom of Hole 797 are in the range of $70^{\circ}-75^{\circ} \mathrm{C}$, which may be low for the formation of analcime. At the time analcime formed, however, temperatures may have reached values in excess of $100^{\circ} \mathrm{C}$ owing to increased heat resulting from intrusion of sills into Site 797 sandstones, and circulation of hot fluids through the sandstones. Also, the rate of fluid flow and porewater composition may have an important effect on zeolite formation. Surdam and Boles (1979) suggest, for example, that heulandite can be caused to transform to analcime or albite by simply lowering the $\mathrm{Ca} / \mathrm{Na}$ ratio of the fluid phase. If the concentration of $\mathrm{SiO}_{2}$ in the fluid is high, heulandite will react to form albite. If it is low, heulandite will react to form analcime.

\section{Clay-mineral Authigenesis}

Authigenic clay minerals are minor constituents of most Site 796 sandstones, although a few samples of Site 796 sandstones contain as much as $6 \%$ authigenic clay minerals (determined petrographically). A clay-mineral content of $1 \%-2 \%$ is more typical, and many samples of the sandstones contain no visible authigenic clay minerals. Most of the authigenic clay minerals are pale green. We are unable to positively identify these clay minerals by X-ray diffraction analysis of bulk samples, and the samples are too small to allow analysis of the $2-\mu \mathrm{m}$ fraction alone. Also, microprobe analysis of clay mineral compositions is inconclusive. Both the $\mathrm{Al}$ and $\mathrm{Mg}$ content of the clay-minerals is low for typical chlorite, and the compositions do not fit smectite perfectly. The clay minerals are most likely chlorite or mixed-layer chlorite-smectite (?). Clay minerals occur primarily as replacement minerals for matrix or framework grains, particularly glass shards, but they may form minor cements in cavities created by dissolution of glass shards (Fig. 3).

Authigenic clay minerals are common constituents of Site 797 sandstones. These sandstones typically contain 3\%-4\% authigenic clays, but some samples contain more than $10 \%$ clay minerals. They occur as a replacement for framework grains and matrix or, less commonly, as cements (Fig. 5). These clay minerals are probably mixed-layer, chlorite-smectite. Dark brown, authigenic clay minerals that are enriched in titanium are also present in Site 797 sandstones. These clay minerals have the approximate chemical composition of illite-smectite. Minor illite, distinguished petrographically by high birefringence, replaces some plagioclase grains along cleavage planes. The diagenetic temperatures of Site 797 sandstones $\left(>\sim 100^{\circ} \mathrm{C}\right.$ ) are compatible with the formation of authigenic chlorite, mixed layer clays, and illite (Fig. 20). The presence of bleached or leached biotite grains in Site 797 sandstones suggests that at least part of the $\mathrm{Mg}$ and $\mathrm{Fe}^{2+}$ needed to form chloritic clays may have been derived from biotite (e.g., Morad and AIDahan, 1987b).

Kaolinite is the most abundant clay mineral in Site 799 sandstones, generally composing $1 \%-3 \%$ of total constituents. It occurs as a cement (Fig. 4) and as a replacement mineral for matrix and framework grains, particularly plagioclase feldspars (Fig. 21). Kaolinite was identified by electron microscopy (Fig. 22) and by microprobe analysis, which shows a nearly $1: 1$ ratio of silica to aluminum, strong depletion in other cations, and the presence of $(\mathrm{OH})$ or water. The 


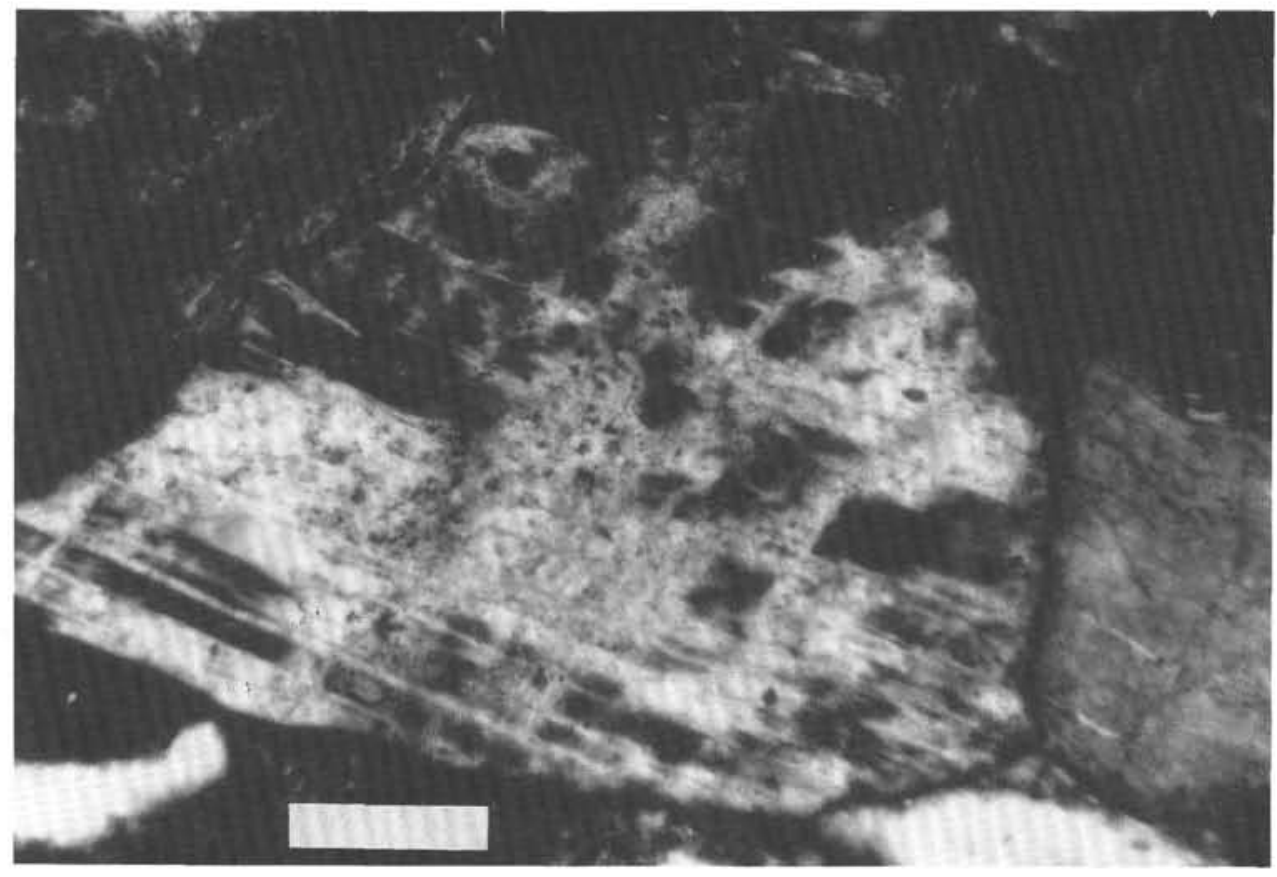

Figure 13. "Blocky" extinction pattern in an albitized, twinned plagioclase grain. Core photograph 128-799B-61R, $\sim 1024$ mbsf. Crossed nicols. Scale bar $=0.1 \mathrm{~mm}$.

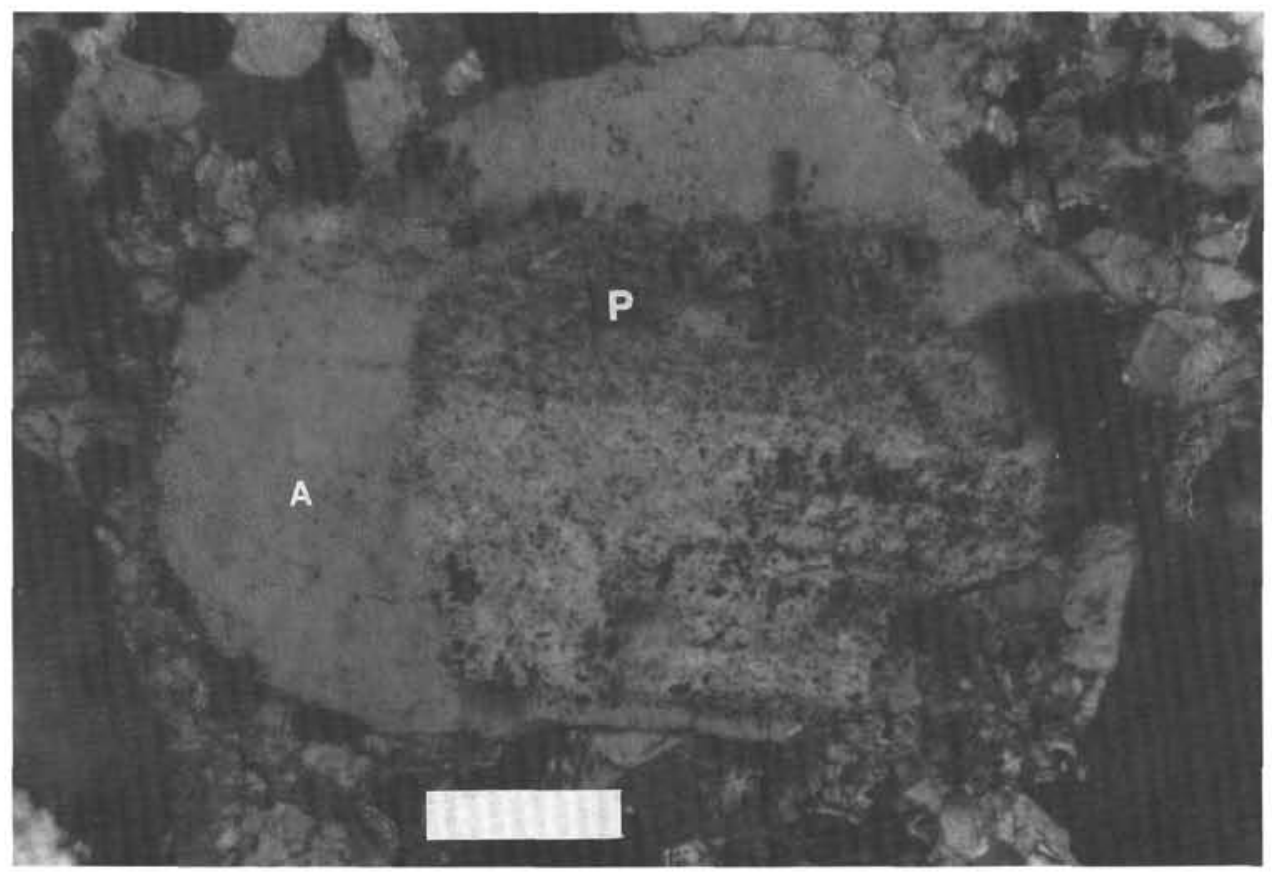

Figure 14. Plagioclase feldspar (P), clouded by clay-mineral alteration products, with a clear syntaxial overgrowth rim of albite (A). Core photograph 128-799B-64R, 1058 mbsf. Crossed nicols. Scale bar $=0.1 \mathrm{~mm}$. 


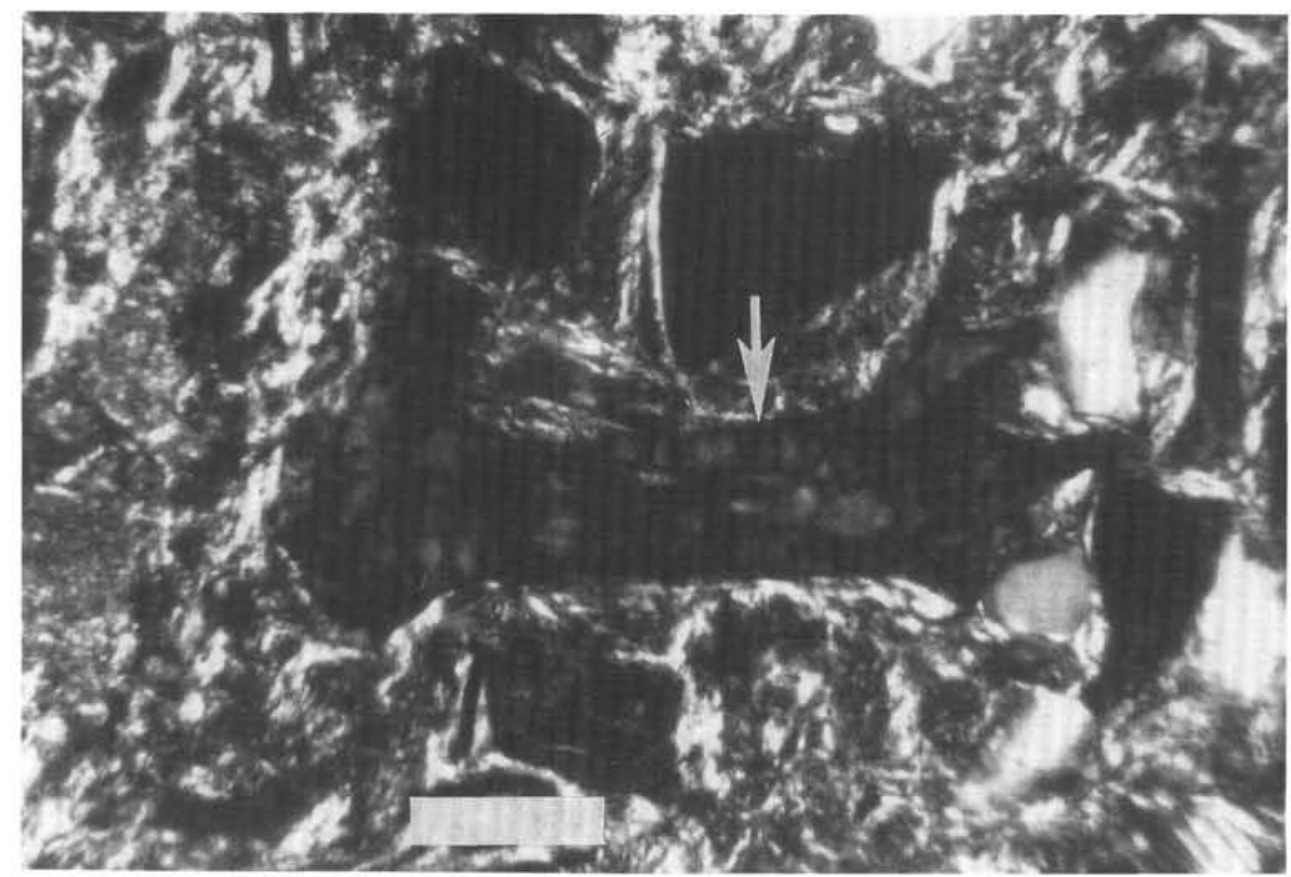

Figure 15. Glass shard (arrow) that has been replaced by zeolites (Na clinoptilolite). Core photograph 127-796B-17R, $\sim 311$ mbsf. Crossed nicols. Scale bar $=0.1 \mathrm{~mm}$.

presence of fairly abundant kaolinite in Site 799 sandstones in contrast to Site 796 and 797 sandstones may be related to the abundance of orthoclase feldspars in Site 799 sandstones. Kaolinite is a common alteration product of K-feldspars (Bjørlykke, 1981; Chamley, 1989, p. 22). Albitization of plagioclase feldspars may also play some role in its formation because kaolinite can precipitate as a by-product of albitization (Boles, 1982). Many of the plagioclase feldspars in Site 799 sandstones show alteration to dark-colored clays (Fig. 23), and some plagioclase grains are almost completely replaced by clay minerals. Other plagioclase grains show extensive alteration to sericite or fine-grained muscovite (Fig. 24).

\section{REPLACEMENT BY CARBONATES, SULFATES, SULFIDES, IRON OXIDES, AND MICROQUARTZ (CHERT)}

\section{Carbonates}

Carbonates are important replacement minerals in Leg 127-128 sandstones, particularly in some matrix-rich Site 796 and 799 sandstones. On the basis of petrographic characteristics and limited microprobe data, the principal carbonate mineral in Site 796 and 797 sandstones appears to be calcite, although dolomite rhombs are present in some Site 796 samples. Dolomite was also detected during electron microprobe analysis of some Site 799 samples.

Carbonate replacement minerals are extremely common in a few Site 796 sandstones, where they reach a maximum abundance of about $12 \%$ of total constituents. They are absent in other Site 796 sandstones. In samples that contain abundant authigenic carbonate minerals, carbonates replace both mud matrix and framework grains. Pumiceous glass fragments appear to be particularly susceptible to replacement. Many volcanic rock fragments (Fig. 25) and plagioclase grains (Fig. 26) have likewise undergone extensive replacement by carbonates. Replacement carbonate minerals are also commonly present in minor amounts in many Site 797 sandstones, and they are abundant in a few sandstones. They typically replace plagioclase grains, volcanic rock fragments, and matrix, and may also replace

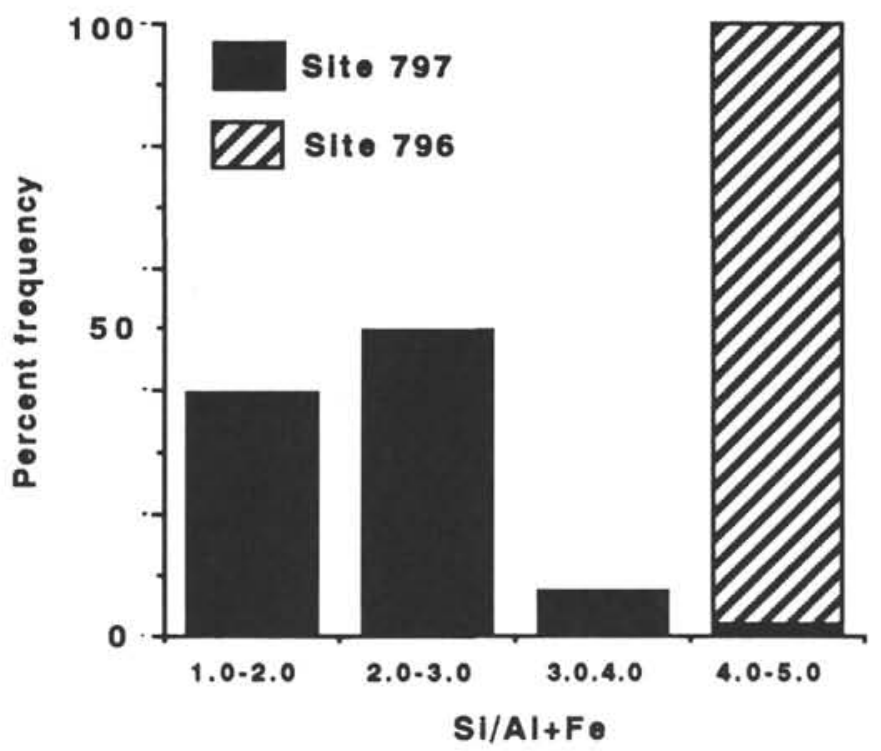

Figure 16. Histogram showing Silica/Al $+\mathrm{Fe}$ ratios of Site 796 and 797 zeolites.

biotite, K-feldspars, and quartz grains. Replacement carbonate is extremely abundant in some matrix-rich Site 799 sandstones, where it makes up $20 \%-40 \%$ of total constituents in a few samples. Carbonates may replace matrix, volcanic rock fragments, plagioclase, orthoclase feldspar (Fig. 27), and even quartz (Fig. 28). On the other hand, some Site 799 sandstones contain no replacement carbonate.

Differences in the extent of carbonate cementation in sandstones at each site probably reflect differences in permeabilities of the sandstones to carbonate-rich pore fluids, although differences in availability of calcium carbonate may be an additional factor. The source of the carbonate in Site 796, 797, and 799 sandstones is not 


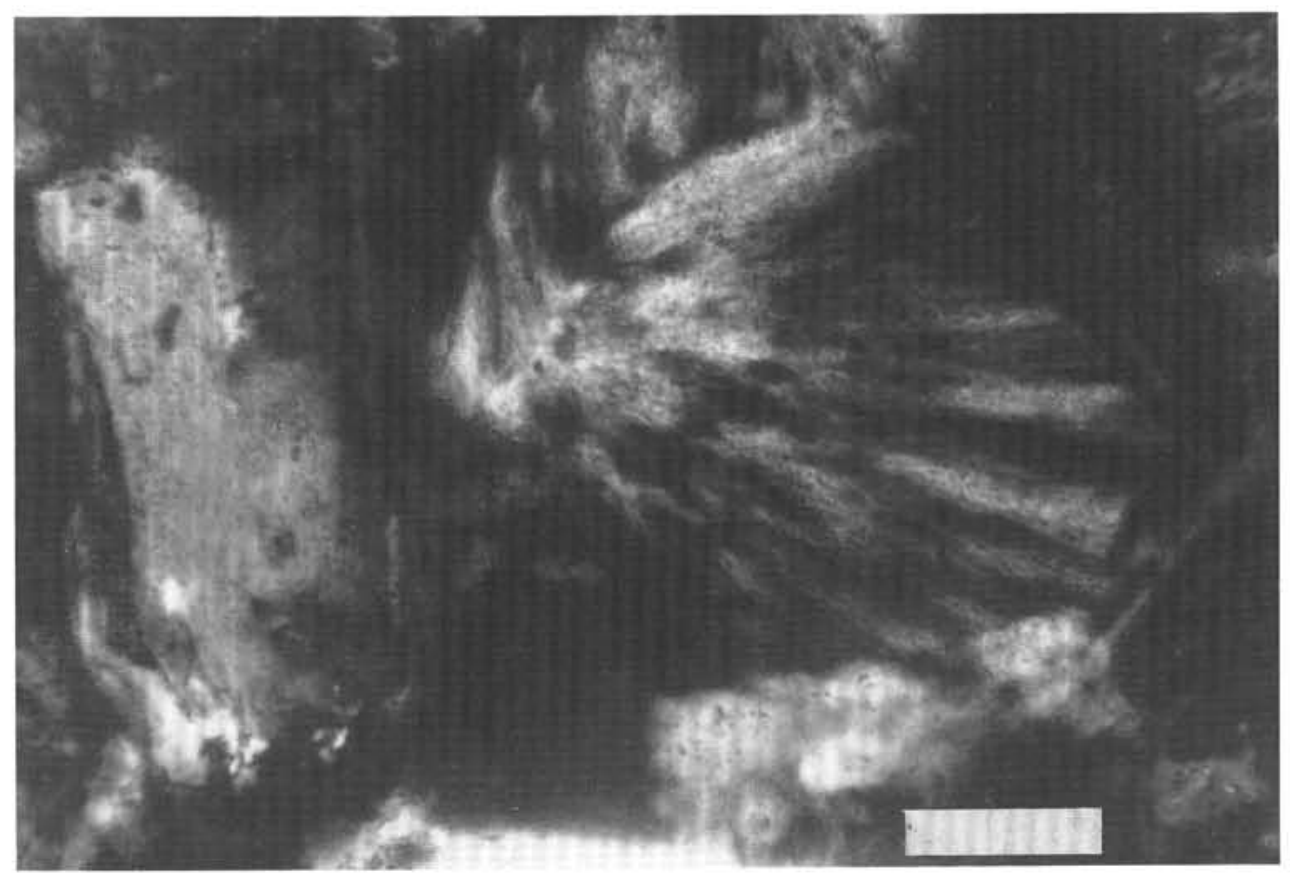

Figure 17. Radiating clusters of zeolite crystals replacing a blocky glass fragment or glassy volcanic rock fragment. Identity of the zeolites uncertain. Core photograph 127-797C-33R, $\sim 738$ mbsf. Crossed nicols. Scale bar $=0.1 \mathrm{~mm}$.

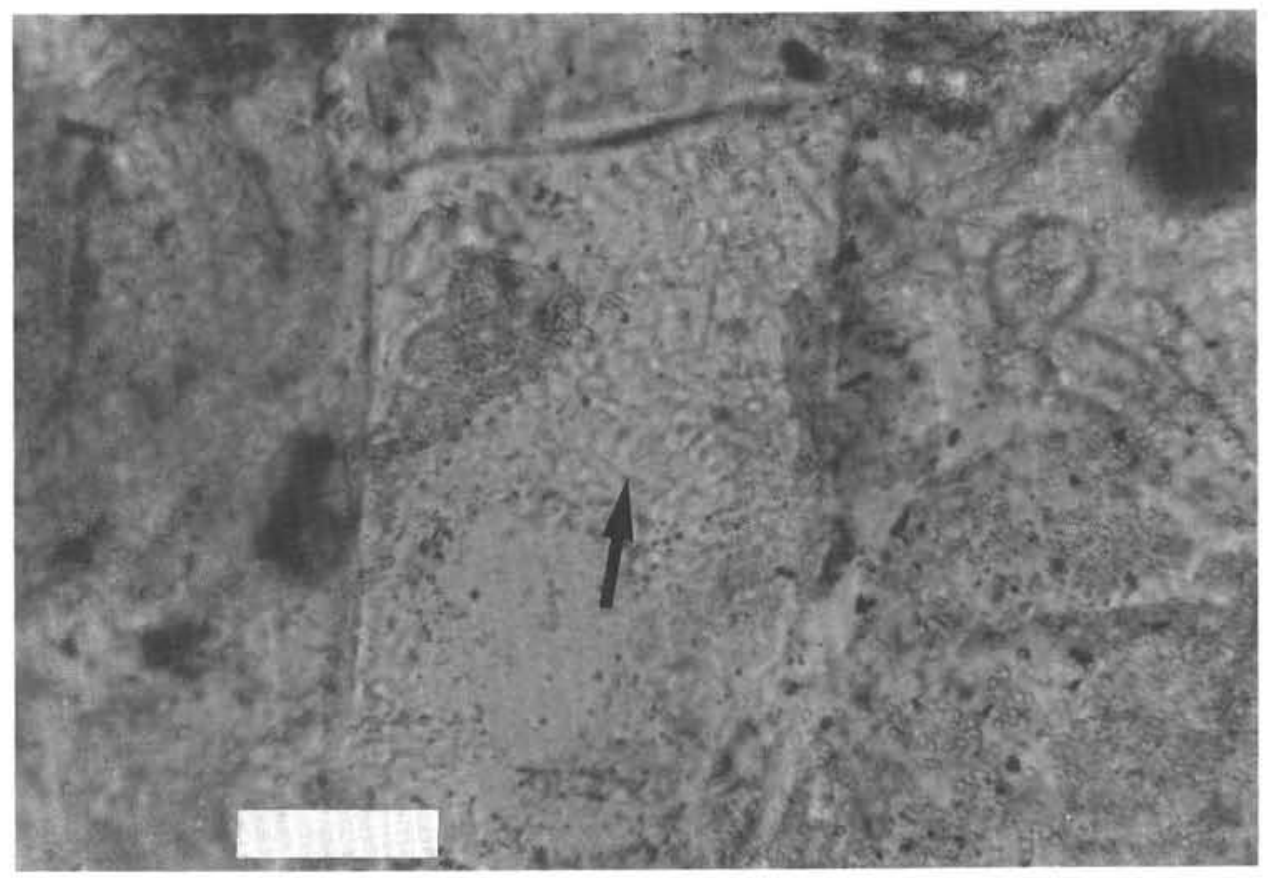

Figure 18. Zeolites (arrow) that partially replace a plagioclase grain (center of photograph). The zeolites may be analcime that forms pseudomorphs after clinoptilolite or heulandite. Core photograph 127-797C-23R, $\sim 696 \mathrm{mbsf}$. Plane-polarized light. Scale bar $=0.5 \mathrm{~mm}$. 


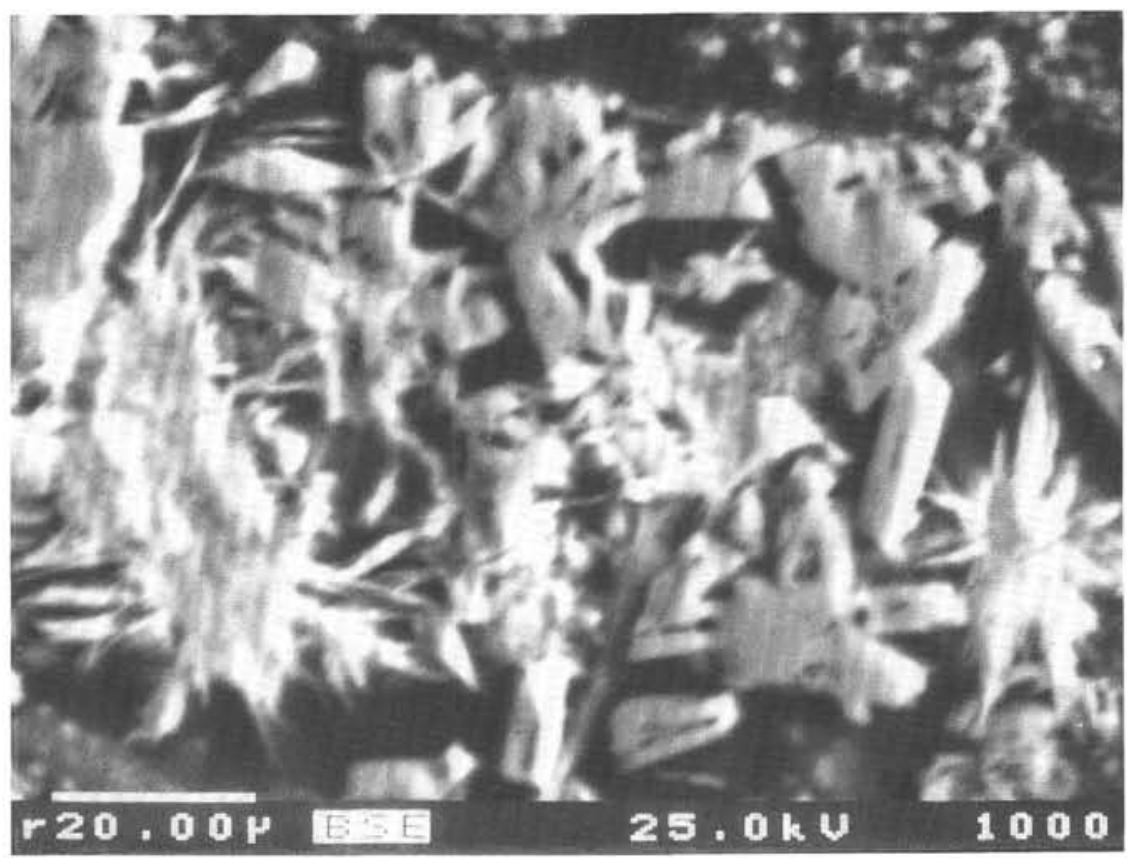

Figure 19. Stellate clusters and tabular crystals of zeolites. Possibly analcime that forms pseudomorphs after clinoptilolite or heulandite (?). Core photograph 127-797C-37R, $\sim 819$ mbsf. Backscattered electron micrograph. Scale bar $=20 \mu \mathrm{m}$.

directly evident from study of the sandstones. Some may have been supplied by dissolution of fossils such as foraminifers within the sandstones or in associated claystones. Additional bicarbonate ions may have been provided by bacterial fermentation of organic matter or decarboxylation reactions involving organic matter. For example, the organic carbon content of some clayey Miocene sediments at Site 797 ranges to $8.5 \%$, and the weight percent organic carbon in lower Miocene sediments at this site averages about $0.6 \%$ (Shipboard Scientific Party, 1990b). Some calcium was probably furnished to Site 797 sandstones by albitization of plagioclase feldspars, and additional calcium may have been imported from altered basaltic sills that intrude the sandstones. Many basalts samples show low calcium abundances (Shipboard Scientific Party, 1990b), suggesting loss of calcium by alteration.

\section{Sulfates, Sulfides, and Iron Oxides}

Authigenic anhydrite and barite are present in many Site 797 sandstones in minor amounts, and anhydrite is typically more abundant than barite. These sulfate minerals commonly replace matrix, volcanic rock fragments, or plagioclase grains (Fig. 29). We found barite in only one sample of Site 799 sandstone, but it makes up about $8 \%$ of the total constituents in that sample. None of the Site 796 sandstones contain sulfate minerals. Anhydrite and barite may be in part the by-product of albitization of plagioclase feldspars. Adequate sulfate to form these minerals is probably residual seawater sulfate that escaped bacterial degradation. For example, at Site 797 sulfate is still present in concentrations of about $10 \mathrm{mmol} / \mathrm{L}$ at depths of about $525 \mathrm{~m}$ (Shipboard Scientific Party, 1990c; data are not available for greater depths.) Sulfate concentration is less than $5 \mathrm{mmol} / \mathrm{L}$ in

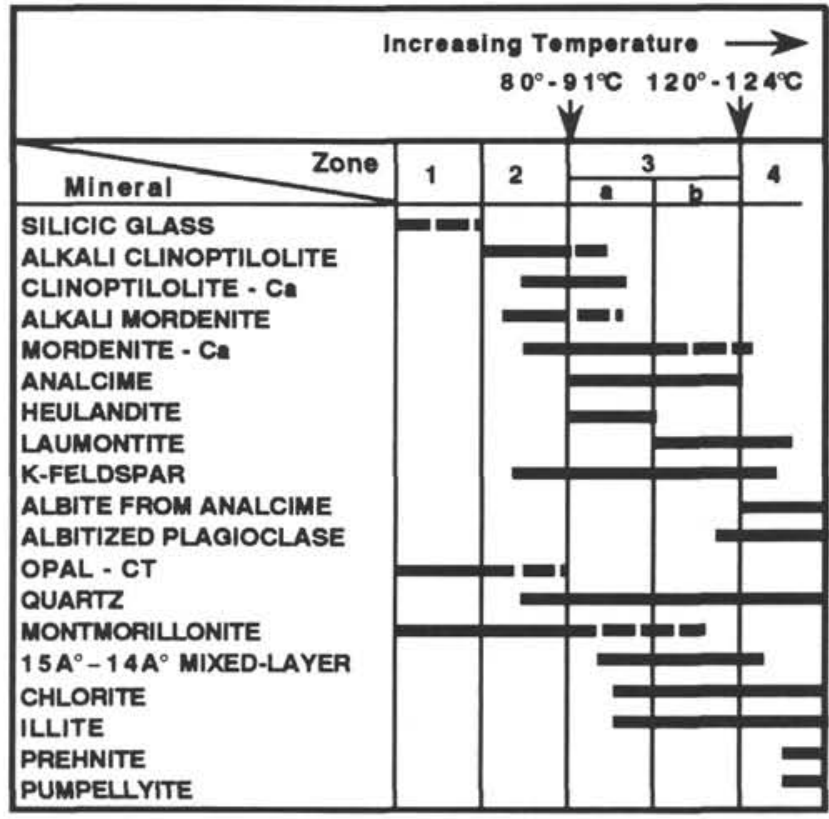

STABLE OR METASTABLE

=1 UNSTABLE

Figure 20. Successive zones of zeolites and other authigenic silicates that formed during burial diagenesis of marine siliciclastic volcaniclastics. Zone 4 grades into the metamorphic regime. (After Iijima, 1978.) 


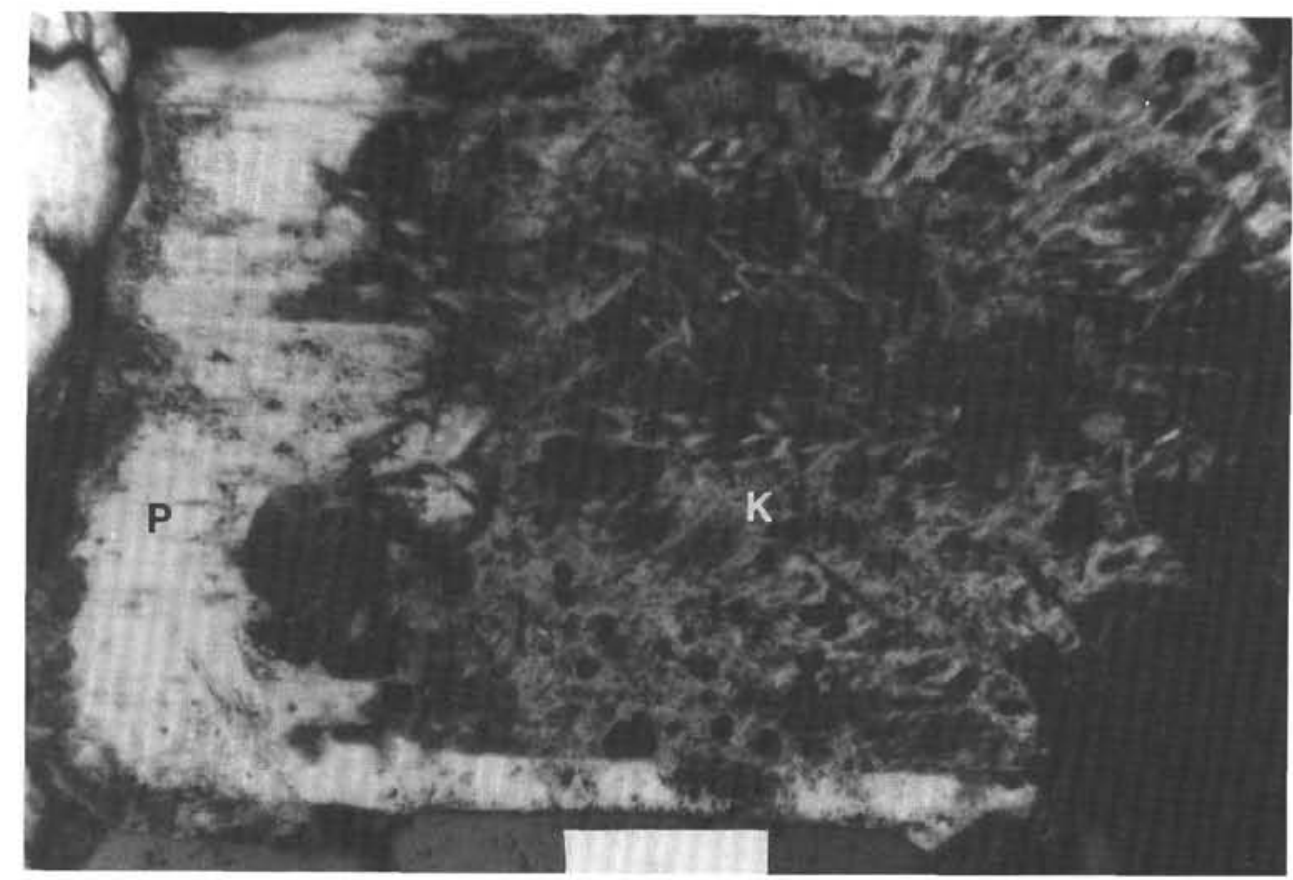

Figure 21. Plagioclase feldspar (P) partially replaced by kaolinite (K). Core photograph 128-799B-61R, 1023 mbsf. Crossed nicols. Scale bar $=0.1 \mathrm{~mm}$.

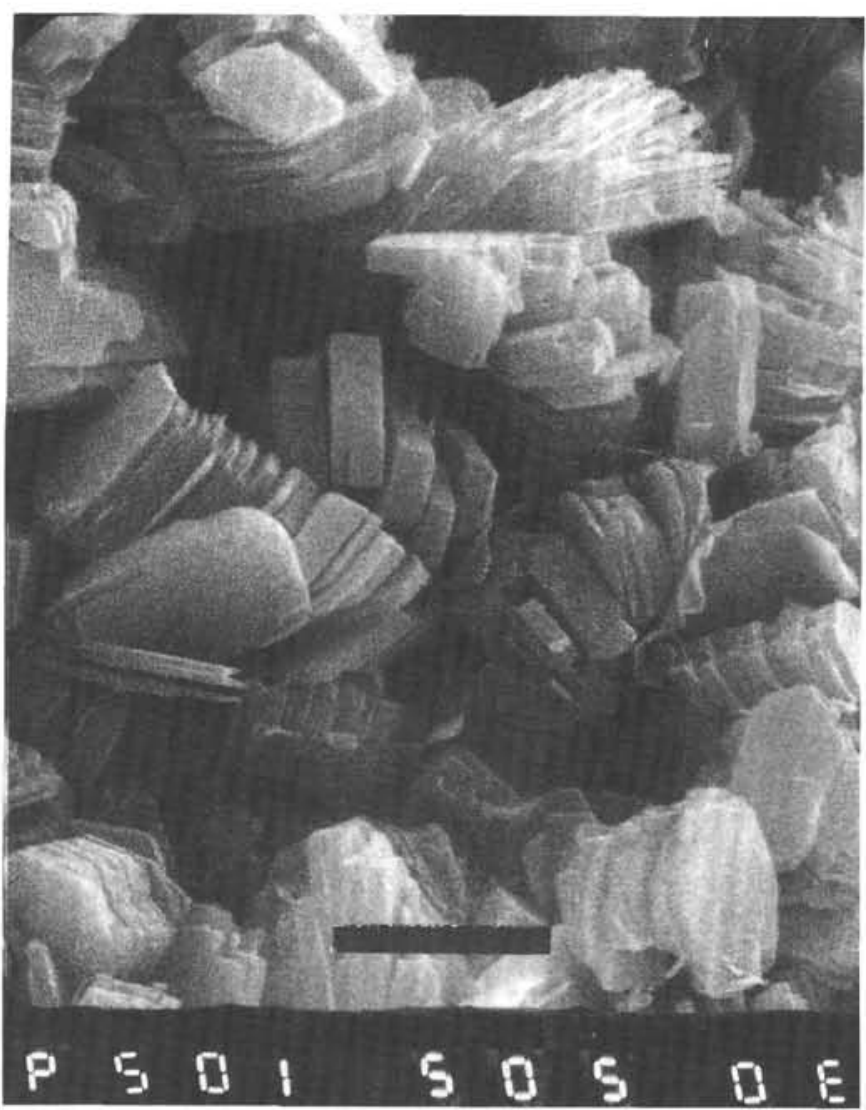

Figure 22. SEM photograph of kaolinite "books." Core 128-799B-67R, $\sim 1078$ mbsf. Scale bar $=20 \mu \mathrm{m}$.
Site 796 sediments to depths of about $200 \mathrm{~m}$, but below $200 \mathrm{~m}$ it increases to nearly $15 \mathrm{mmol} / \mathrm{L}$. Nonetheless, we do not find sulfate minerals in Site 796 sandstones. The absence of sulfate minerals may be related to the absence of albitization in these sandstones, which could provide a source of calcium, or it may simply mean that all available calcium was tied up in formation of carbonate minerals. At Site 799, sulfate is essentially depleted in pore waters at a depth of only about $30 \mathrm{mbsf}$ (Shipboard Scientific Party, 1990c). The reason for abundant authigenic barite in the one Site 799 sample mentioned above is not clear.

Pyrite occurs throughout Site 796, 797, and 799 sandstones. It is present both as framboids (spheroidal clusters) and larger, irregular masses. It typically replaces carbonaceous or woody fragments, but it may also replace matrix, volcanic rock fragments, plagioclase feldspars, biotite, and quartz. It also replaces authigenic anhydrite in some Site 797 sandstones. Pyrite is a common authigenic mineral in sediments where reducing conditions prevail and where an adequate source of iron and sulfur is available (Burley et al., 1985). Sulfur was probably available in Site 796, 797, and 799 sandstones owing to bacterial degradation of sulfates. Ferrous iron is present in volcanic rock fragments and mafic minerals such as biotite. A puzzling aspect of many sandstone samples, particularly Site 796 and 797 samples, is the presence of grains that have been replaced by pyrite (containing $\mathrm{Fe}^{2+}$ ) and grains that have been altered to hematite (containing $\mathrm{Fe}^{3+}$ ) in the same sample. Many, but not all, of the grains that have been partially replaced by hematite are glassy volcanic rock fragments. Reed (1983) has shown in seawater-basalt reactions that ferrous iron can be oxidized by sulfate and stored in ferric hydroxide complexes until hematite is precipitated. Sulfide sulfur produced by sulfate reduction from seawater is stored as pyrite. Thus, both hematite and pyrite can theoretically form authigenically in the same rocks.

\section{Microquartz (Chert)}

Authigenic microquartz (chert) is present only in Site 797 sandstones. It occurs in only in two of these sandstones, one near the top of the sandstone section (Fig. 2) and one near the bottom of the hole. 


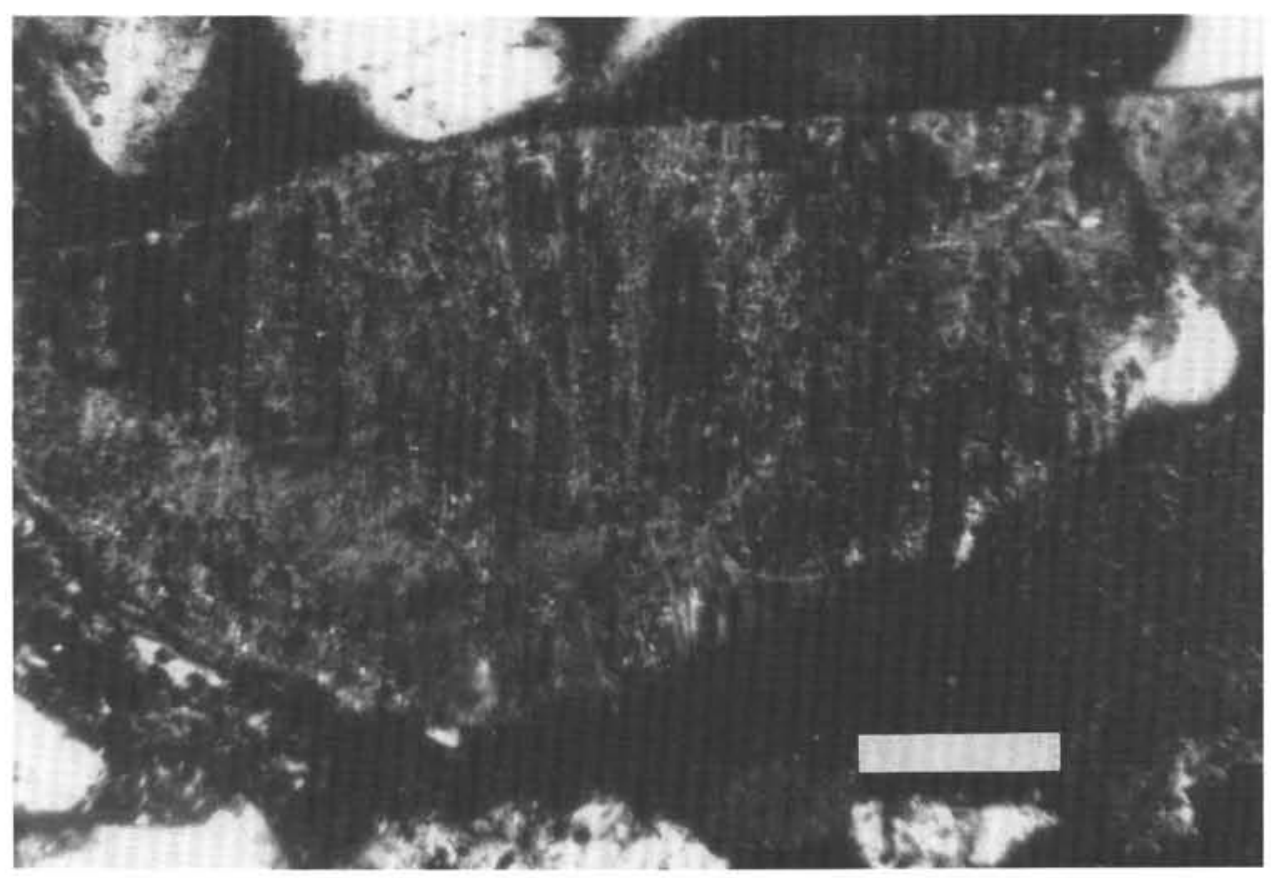

Figure 23. Plagioclase grain totally clouded by dark, clay-mineral alteration products. Core photograph 128-799B-61R, $\sim 1020 \mathrm{mbsf}$. Crossed nicols. Scale bar $=0.1 \mathrm{~mm}$.

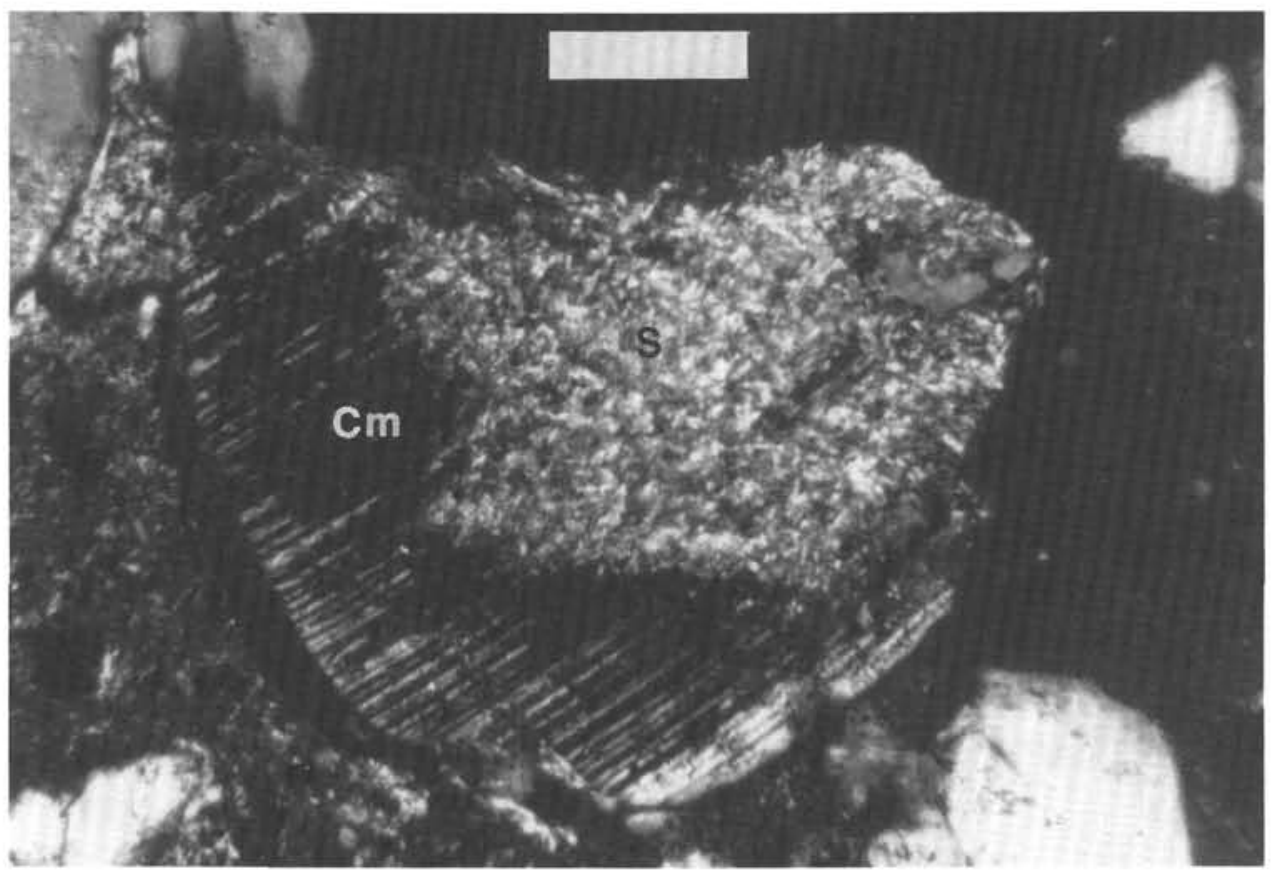

Figure 24. Broken, twinned plagioclase grain partially replaced by sericite $(\mathrm{S})$ and dark-colored clay minerals $(\mathrm{Cm})$. Core photograph 128-799B-61 R, 1024 mbsf. Crossed nicols. Scale bar $=0.1 \mathrm{~mm}$. 


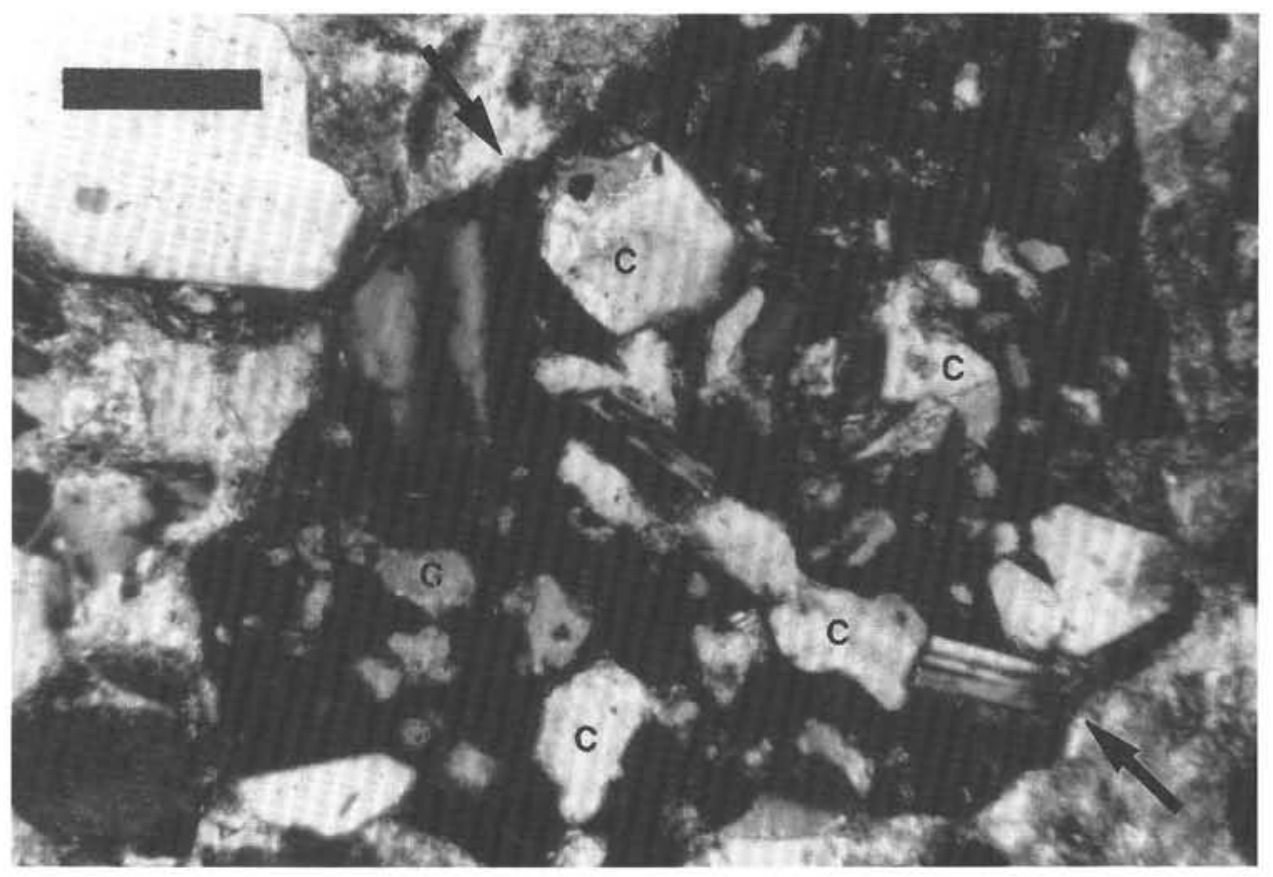

Figure 25. Glassy volcanic rock fragment (arrows) with numerous patches of replacement calcite (C). Core photograph 127-796B-11R, 253 mbsf. Crossed nicols. Scale bar $=0.1 \mathrm{~mm}$.

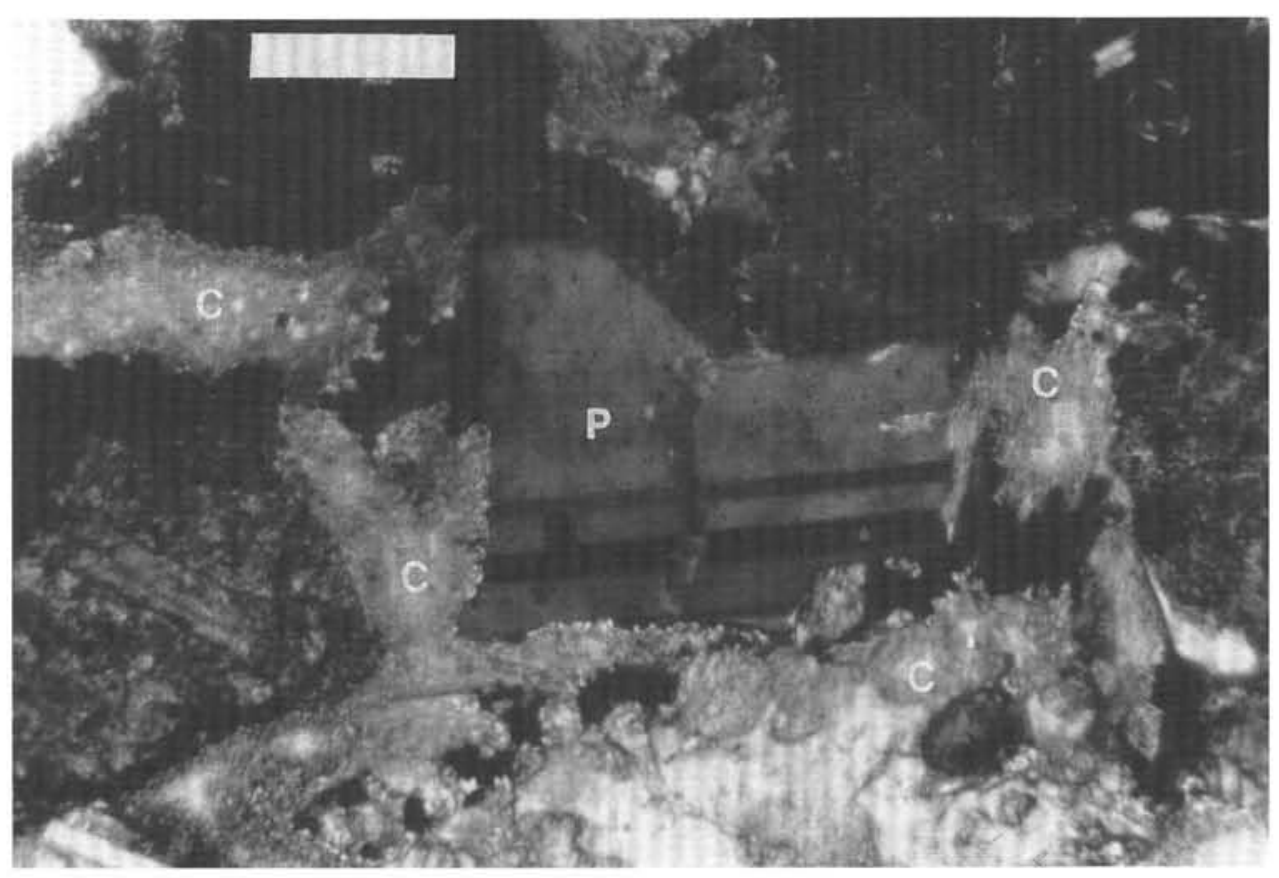

Figure 26. Twinned plagioclase (P) strongly embayed by replacement calcite (C). Core photograph 127-796B-16R, $\sim 310$ mbsf. Crossed nicols. Scale bar $=0.1 \mathrm{~mm}$. 


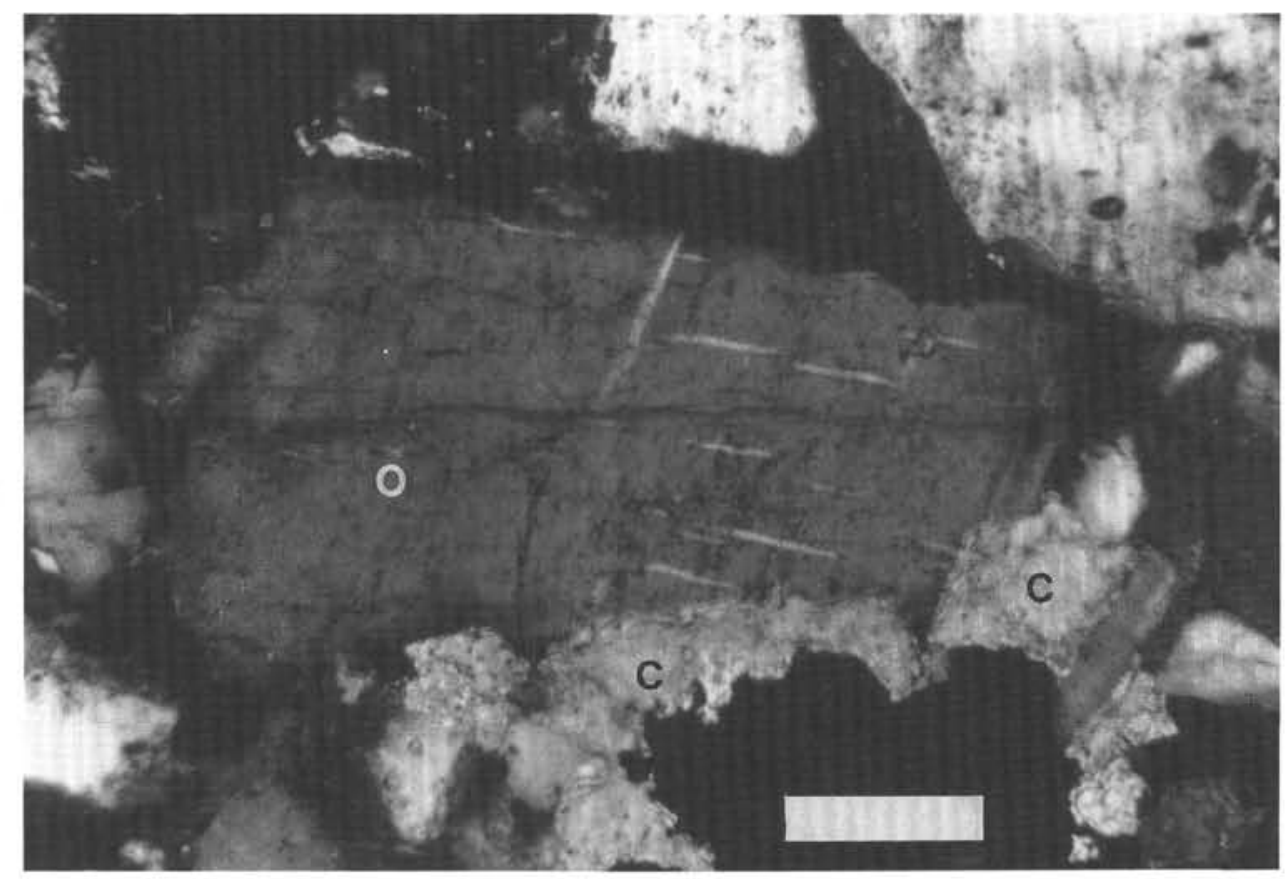

Figure 27. Perthitic orthoclase feldspar $(\mathrm{O})$ partially replaced along one edge by calcite $(\mathrm{C})$. Core photograph 128-799B-65R, $\sim 1061$ mbsf. Crossed nicols. Scale bar $=0.1 \mathrm{~mm}$.

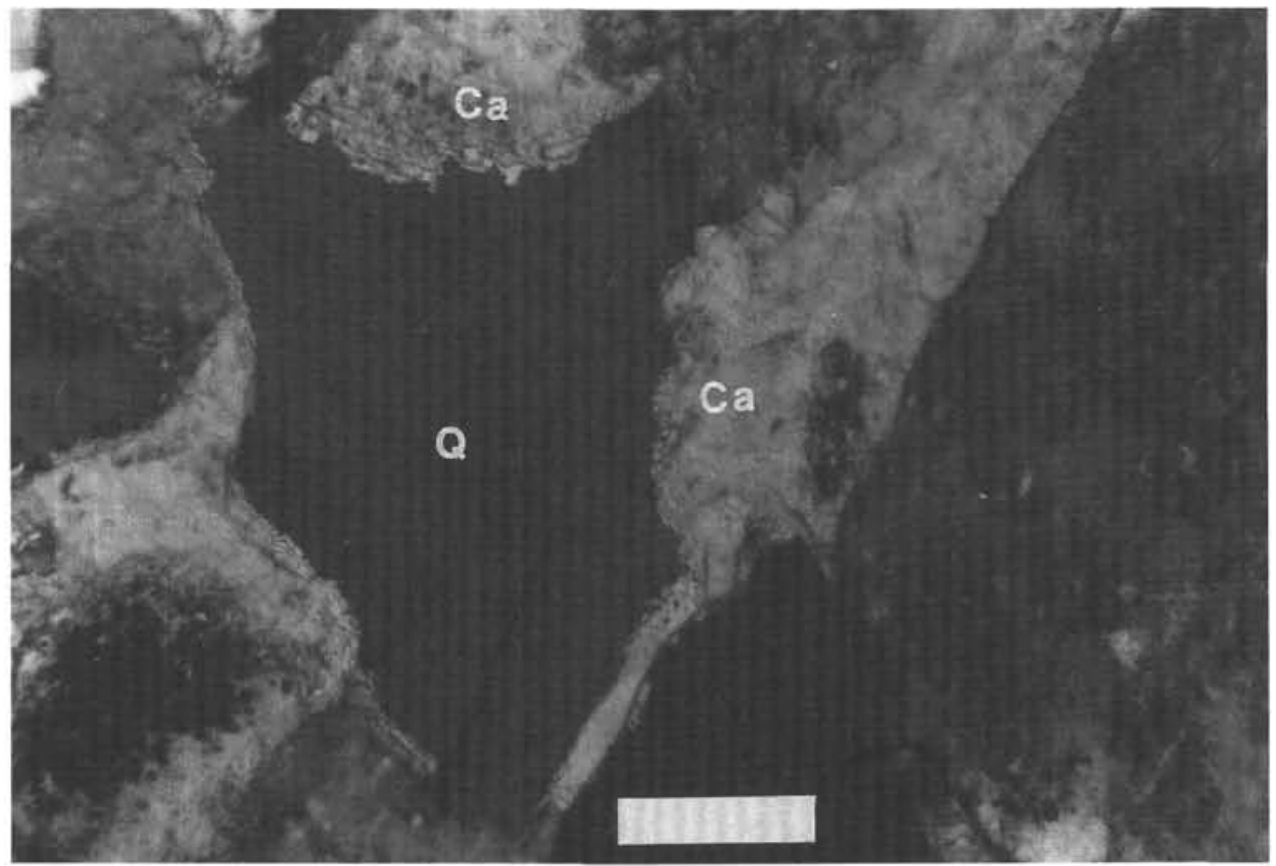

Figure 28. Monocrystalline quartz (Q) grain partially replaced along margins by carbonate (Ca). Core photograph 128-799B-65R, $\sim 1060 \mathrm{mbsf}$. Crossed nicols. Scale bar $=0.1 \mathrm{~mm}$. 


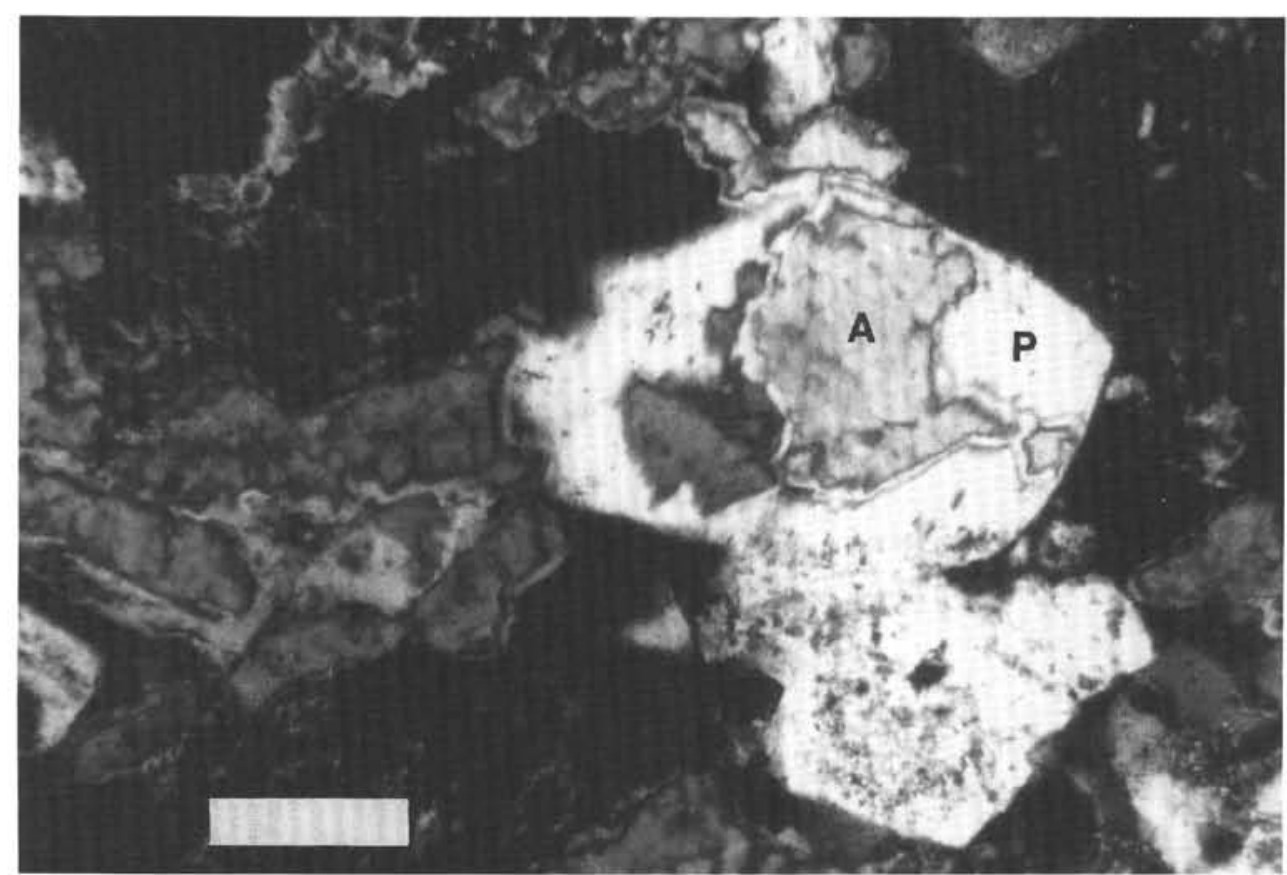

Figure 29. Untwinned plagioclase (P) partially replaced by anhydrite (A). Core photograph 127-797C-41R, 855 mbsf. Crossed nicols. Scale bar $=0.1 \mathrm{~mm}$.

Microquartz commonly partially replaces plagioclase feldspars, volcanic rock fragments, glass shards, and mudstone ripup clasts. It also forms a cement in a few samples. The silica required to form the microquartz was probably furnished by dissolution of glass shards within the sandstones or in associated tuffs. Albitization of feldspars and zeolites and replacement of plagioclase feldspars by chlorite may also release silica (Morad and AlDahan, 1987a). The two sandstones in which microquartz occurs are coarser grained than other sandstones at Site 797. The presence of microquartz in these sandstones may thus be related to greater permeability of these sandstones.

\section{DISCUSSION-PROVENANCE LOSS OWING TO DIAGENESIS}

The most important changes that have occurred in Site 796, 797, and 799 sandstones owing to diagenesis are the result of albitization of feldspars and the replacement of framework grains and matrix by zeolites, carbonates, and clay minerals. Replacement by minor amounts of anhydrite and barite is also common in some Site 797 sandstones. All of these processes act to destroy framework grains. Therefore, they may create problems in sandstone classification and provenance interpretation. Dissolution can also destroy framework grains; however, we see only minor evidence of dissolution in the Japan Sea sandstones.

Albitization has been an especially important process in destroying provenance information in Site 797 and 799 sandstones. Many of the plagioclase feldspars in the sandstones at these two sites have been albitized. Although the grains can still be recognized as plagioclase, their usefulness in provenance interpretation is diminished because their chemical compositions cannot be used as a guide to the compositions of their parent rocks (Helmold, 1985). Also, some volcanic rock fragments in Site 797 sandstones have lost their identity owing to albitization.

Replacement of framework grains in Site 796 and 797 sandstones by zeolites has also destroyed their identity. Some zeolitized glass shards (Fig. 15) and feldspars can still be recognized by their distinctive shapes (pseudomorphs); however, many completely zeolitized grains do not have distinctive shapes. We are unable to tell whether these grains were originally blocky glass, or possibly feldspars or rock fragments. For example, more than 5\% of the framework grains in a few Site 796 sandstones are so completely zeolitized that the identity of the original grains cannot be established. Many framework grains in Site 797 sandstones have been similarly affected by zeolitization. Replacement by other minerals, particularly carbonate minerals, has also destroyed framework grains. In some samples, identifiable remnants of the framework grains remain; however, many grains have been completely eliminated by replacement processes. Significant amounts, perhaps as much as $5 \%-10 \%$, of the framework grains in some sandstones, particularly a few Site 799 sandstones, have been destroyed by carbonate replacement. On the other hand, little or no destruction of framework grains by carbonate replacement has taken place in many sandstones. As mentioned, these differences in the extent of carbonate replacement probably reflect differences in fluid permeabilities within different sandstone beds. Much fine-size glass (matrix glass) is also destroyed by alteration to mixed-layer clay minerals or zeolites.

\section{SUMMARY AND CONCLUSIONS}

All of the sandstones at Sites 796, 797, and 799 in the Japan Sea have been affected to some degree by diagenetic processes that altered or destroyed matrix and framework grains. The most important diagenetic processes were albitization of plagioclase feldspars and replacement of matrix and framework grains by zeolites, carbonates, clay minerals, sulfates, and sulfides. Chemical diagenetic processes were controlled by pore-fluid chemistry and diagenetic temperatures. Diagenetic temperatures in Hole 796 probably ranged between about $40^{\circ}$ and $65^{\circ} \mathrm{C}$. Measured temperatures extrapolated to the bottom of Hole 797 are about $75^{\circ} \mathrm{C}$; however, intrusion of basaltic sills into the bottom of the sediment column at Site 797 may have increased 
diagenetic temperatures to over $100^{\circ} \mathrm{C}$ and introduced hot fluids enriched in elements such as $\mathrm{Na}$ and $\mathrm{Ca}$. Extrapolated temperatures at the bottom of Hole 799 are about $100^{\circ} \mathrm{C}$.

Site 796 sandstones have not been affected by albitization, probably owing to the low diagenetic temperatures at this site. Also, Site 796 sandstones are younger than Site 797 and Site 799 sandstones and thus have had less time to become altered. On the other hand, matrix, as well as many framework grains (plagioclase grains, glass, volcanic rock fragments) have undergone considerable replacement by zeolites and carbonate minerals, and to a lesser extent by clay minerals.

Most of the plagioclase feldspars in Site 797 sandstones, which were subjected to higher diagenetic temperatures than were Site 796 sandstones, have been replaced by albite. Also, the common presence of carbonates and minor authigenic anhydrite and barite in Site 797 sandstones may be related to release of calcium by albitization of plagioclase. In addition, alteration of volcanic glass and volcanic rock fragments to mixed-layer clay minerals has been extensive, and some matrix has also been replaced by clay minerals. Replacement of matrix and framework grains by carbonates and zeolites is also common.

Many of the plagioclase feldspars in Site 799 sandstones have also been replaced by albite. Albitization is consistent with diagenetic temperatures of almost $100^{\circ} \mathrm{C}$. Few, if any, zeolites are present in these sandstones. The absence of zeolites probably reflects the fact that Site 799 sandstones are feldspathic sandstones (arkoses), in contrast to Site 796 and 799 volcaniclastic sandstones, and thus do not contain abundant glass and glassy volcanic rock fragments that are easily altered to zeolites. Site 799 sandstones contain a few percent kaolinite, which occurs as a cement or as a replacement for matrix. Kaolinite is a common alteration product of K-feldspars. Its presence in Site 799 sandstones is probably related to the abundance of orthoclase feldspars in these sandstones and to albitization of plagioclase feldspars.

\section{ACKNOWLEDGMENTS}

We wish to thank the Ocean Drilling Program, Texas A\&M University, for furnishing the samples for this study. Funds for the research were provided by the National Science Foundation (Grant No. EAR 8903497) through the Ocean Drilling Program. Michael Schaeffer and Roy Torley, Department of Geological Sciences, University of Oregon, provided technical assistance with electron microprobe analyses and data reduction. We also thank David Krinsley, University of Arizona, for advice on backscattered electron microscopy and for examining some of our samples by backscattered microscopy. Editorial comments by Kathleen M. Marsaglia are greatly appreciated.

\section{REFERENCES}

Aagaard, P., Egeberg, P. K., Saigal, G. C., Morad, S., and Bjørlykke, K., 1990. Diagenetic albitization of detrial K-feldspars in Jurassic, Lower Cretaceous and Tertiary clastic reservoir rocks from offshore Norway, 11. Formation water chemistry and kinetic considerations. J. Sediment. Petrol., 60:575-581.

AlDahan, A. A., Morad, S., and Collini, B., 1987. Clouded-untwinned albite in the Siljan granite, central Sweden. N. Jahrb. Mineral. Monatsh. 1987:327-335.

Bjørlykke, K., 1981. Diagenetic reactions in sandstones. In Parker, A., and Sellwood, B. W. (Eds.), Sediment Diagenesis: Dordrecht (D. Reidel), 169-213.

Boles, J. R., 1981. Zeolites in low-grade metamorphic rocks. In Mumpton, F. A. (Ed.), Mineralogy and Geology of Natural Zeolites. Mineral. Soc. Am., Rev. Mineral., 4:103-135.

, 1982. Albitization of plagioclase, Gulf Coast Tertiary. Am. J. Sci., 282:165-180

Burley, S. D., Kantorowitz, J. D., and Waugh, B., 1985. Clastic diagenesis. In Brenchley, P. J., and Williams, B.P.J. (Eds.), Sedimentology: Recent Developments and Applied Aspects: Oxford (Blackwell Sci. Publ.), 189-226.

Chamley, H., 1989. Clay Sedimentology: Heidelberg (Springer Verlag).
Deer, W. A., Howie, R. A., and Zussman, J., 1966. An Introduction to the Rock-forming Minerals: London (Longman Group Ltd.).

Gold, P. B., 1987. Textures and geochemistry of authigenic albite from Miocene sandstones, Louisiana Gulf Coast. J. Sediment. Petrol., 57:353-362.

Hay, R. L., 1981. Geology of zeolites in sedimentary rocks. In Mumpton, F. A. (Ed.), Mineralogy and Geology of Natural Zeolites. Rev. Mineral., 4:53-64.

Helmold, K. P., 1985. Provenance of feldspathic sandstones - the effects of diagenesis on provenance interpretations: a review. In Zuffa, G. G. (Ed.), Provenance of Arenites: Dordrecht (D. Reidel), 139-163.

Iijima, A., 1978. Geological occurrences of zeolite in marine environments. In Sand, L. B., and Mumpton, F. A., (Eds.), Natural Zeolites Occurrence, Properties, Use: Oxford (Pergamon Press), 175-198.

Kastner, M., and Siever, R., 1979. Low temperature feldspars in sedimentary rocks. Am. J. Sci., 279:435-479.

Milliken, K. L., 1988. Loss of provenance information through subsurface diagenesis in PlioPleistocene sandstones, northern Gulf of Mexico: J. Sediment. Petrol., 58:992-1002.

, 1989. Petrography and composition of authigenic feldspars, Oligocene Frio Formation, south Texas. J. Sediment. Petrol., 59:361-374.

Milliken, K. L., Land, L. S., and Loucks, R. G., 1981. History of burial diagenesis determined from isotopic geochemistry, Frio Formation, Brazoria County, Texas. AAPG Bull., 65:1397-1413.

Morad, S., and AlDahan, A. A., 1987a. Diagenetic replacement of feldspars by quartz in sandstones. J. Sediment. Petrol., 57:488-493.

1987b. Diagenetic chloritization of feldspars in sandstones. Sediment. Geol., 51:155-164.

Morad, S., Bergan, M., Knarud, R., and Nystuen, J. P., 1990. Albitization of detrital plagioclase in Triassic reservoir sandstones from the Snorre Field, Norwegian North Sea. J. Sediment. Petrol., 60:411-425.

Nesse, W. D., 1991. Introduction to Optical Mineralogy (2nd ed.): Oxford (Oxford Univ. Press).

Ogihara, S., and Iijima, A., 1989. Clinoptilolite to heulandite transformation in burial diagenesis. In Jacobs, P. A., and van Santen, R. A. (Eds.), Zeolites: Facts, Figures, Future: Amsterdam (Elsevier Sci. Publ.), 491-500.

Reed, M. H., 1983. Seawater-basalt reaction and the origin of greenstones and related ore deposits. Econ. Geol., 78:466-485.

Saigal, G. C., Morad, S., Bjørlykke, K., Egeberg, P. K., and Aagaard, P., 1988. Diagenetic albitization of detrital K-feldspars in Jurassic, Lower Cretaceous, and Tertiary clastic reservoir rocks from offshore Norway, 1. Textures and origin. J. Sediment. Petrol., 58:1003-1013.

Sheppard, R. A., and Gude, A. J., 1973. Zeolites and associated authigenic minerals in tuffaceous rocks of the Big Sandy Formation, Mohave County, Arizona. Geol. Surv. Prof. Pap. U.S., 830.

Shipboard Scientific Party, 1990a. Site 796. In Tamaki, K., Pisciotto, K., Allan, J., et al., Proc. ODP, Init. Repts., 127: College Station, TX (Ocean Drilling Program), 247-322.

, 1990b. Site 797. In Tamaki, K., Pisciotto, K., Allan, J., et al., Proc. ODP, Init. Repts., 127: College Station, TX (Ocean Drilling Program), $323-421$.

_ 1990c. Site 799. In Ingle, J. C., Jr., Suyehiro, K., von Breymann, M. T., et al., Proc. ODP, Init. Repts., 128: College Station, TX (Ocean Drilling Program), 237-402.

Surdam, R. C., 1981. Zeolites in closed hydrologic systems. In Mumpton, F. A. (Ed.), Mineralogy and Geology of Natural Zeolites. Mineral. Soc. Am., Rev. Mineral., 4:65-91.

Surdam, R. C., and Boles, J. R., 1979. Diagenesis of volcanic sandstones. In Scholle, P. A., and Schluger, P. R. (Eds.), Aspects of Diagenesis. Spec. Publ., Soc. Econ. Paleontol. Mineral., 26:227-242.

Surdam, R. C., Crossey, L. J., Hagen, E. S., and Heasler, H. P., 1989. Organic-inorganic interactions and sandstone diagenesis. AAPG Bull., 73:1-23.

Taylor, J. M., 1950. Pore-space reduction in sandstones. AAPG Bull., 34:701-716.

Trevena, A. S., and Nash, W. P., 1981. An electron microprobe study of detrital feldspars. J. Sediment. Petrol., 51:137-150.

Walker, T. R., 1984. Diagenetic albitization of potassium feldspars in arkosic sandstones. J. Sediment. Petrol., 54:3-16.

Date of initial receipt: 18 March 1991

Date of acceptance: 16 September 1991

Ms 127/128B-190 
APPENDIX

Samples analyzed in this study by using petrographic, $\mathbf{X}$-ray diffraction, electron microprobe, scanning electron microscopy, and backscattered electron microscopy.

\begin{tabular}{|c|c|c|c|c|c|c|c|}
\hline \multirow[b]{2}{*}{ Sample No. } & \multirow[b]{2}{*}{ mbsf } & \multirow[b]{2}{*}{ Age } & \multicolumn{5}{|c|}{ Type of Sample } \\
\hline & & & Petrographic & XRD & Probe & SEM & Backscatter \\
\hline \multicolumn{8}{|l|}{ 127-796B- } \\
\hline $11 \mathrm{R}-1,8 \mathrm{~cm}$ & 252.8 & I. Mio & $x$ & & & & \\
\hline $11 \mathrm{R}-1,26$ & 253.0 & " & $x$ & & & & \\
\hline $11 \mathrm{R}-1,41$ & 253.1 & " & $x$ & & & & \\
\hline $11 \mathrm{R}-1,62$ & 253.3 & " & $\mathrm{x}$ & & $\mathrm{x}$ & & \\
\hline $11 \mathrm{R}-2,43$ & 254.6 & $n$ & $\mathrm{x}$ & $\mathrm{x}$ & & & \\
\hline $11 R-2,131$ & 255.5 & $"$ & $\mathrm{x}$ & $\mathrm{x}$ & $x$ & & \\
\hline $12 \mathrm{R}-2,120$ & 265.0 & $"$ & $\mathrm{x}$ & & $\mathrm{x}$ & & $\mathrm{x}$ \\
\hline 12R-CC, 13 & 271.9 & $"$ & & & $\mathrm{x}$ & & \\
\hline 16R-CC, 8 & 310.6 & $"$ & $x$ & & $\mathrm{x}$ & & \\
\hline $17 \mathrm{R}-1,58$ & 311.3 & $"$ & & & $x$ & & \\
\hline $17 \mathrm{R}-1.73$ & 311.4 & $"$ & $x$ & $x$ & $\mathrm{x}$ & $\mathrm{x}$ & \\
\hline $18 \mathrm{R}-3,19$ & 323.6 & $"$ & & & $\hat{x}$ & & \\
\hline $18 \mathrm{R}-3,138$ & 324.8 & $"$ & & & $\mathrm{x}$ & & \\
\hline $18 \mathrm{R}-4,129$ & 326.2 & $"$ & $\mathrm{x}$ & $\mathrm{x}$ & & & \\
\hline $19 \mathrm{R}-1,105$ & 331.1 & $"$ & & & $\mathrm{x}$ & & \\
\hline $23 \mathrm{R}-1,13$ & 368.2 & $"$ & $x$ & & & & \\
\hline $25 \mathrm{R}-1,55$ & 388.0 & $"$ & $\mathrm{x}$ & & & & \\
\hline $26 \mathrm{R}-2,58$ & 399.2 & " & $x$ & & & & \\
\hline $28 \mathrm{R}-1,34$ & 416.8 & " & $\mathrm{x}$ & $x$ & & & \\
\hline \multicolumn{8}{|l|}{$127-797 \mathrm{C}$ - } \\
\hline $19 \mathrm{R}-4,103 \mathrm{~cm}$ & 661.6 & e. Mio & $\mathrm{x}$ & & & & \\
\hline $22 \mathrm{R}-2,22$ & 686.8 & $"$ & $\mathrm{x}$ & & & & \\
\hline $22 \mathrm{R}-2,84$ & 687.4 & $"$ & $\mathrm{x}$ & & & & \\
\hline $22 \mathrm{R}-3,24$ & 688.3 & $"$ & $\mathrm{x}$ & & & & \\
\hline $22 \mathrm{R}-3,70$ & 688.8 & $"$ & $x$ & $\mathrm{x}$ & $x$ & & \\
\hline $22 R-4,69$ & 690.3 & $"$ & $\mathrm{x}$ & & & & \\
\hline $22 \mathrm{R}-6,3$ & 692.6 & $"$ & $\mathrm{x}$ & & & & \\
\hline $22 \mathrm{R}-6,99$ & 693.6 & $"$ & $x$ & & & & \\
\hline $23 \mathrm{R}-1,47$ & 695.1 & $"$ & $\mathrm{x}$ & & & & \\
\hline $23 \mathrm{R}-1,100$ & 695.6 & $"$ & $x$ & & $x$ & & \\
\hline $23 \mathrm{R}-3,22$ & 697.8 & $"$ & $x$ & $x$ & & & \\
\hline $23 \mathrm{R}-3,69$ & 799.8 & $"$ & $x$ & & & & \\
\hline $23 \mathrm{R}-4,89$ & 700.0 & $"$ & $x$ & & $x$ & & \\
\hline $23 \mathrm{R}-4,138$ & 700.5 & $"$ & $\mathrm{x}$ & $x$ & & & \\
\hline $25 \mathrm{R}-1,73$ & 714.3 & $"$ & $\mathrm{x}$ & & & & \\
\hline $25 \mathrm{R}-1,139$ & 715.0 & $"$ & $x$ & & $\mathrm{x}$ & & \\
\hline $25 \mathrm{R}-2,16$ & 715.3 & $"$ & $\mathrm{x}$ & & & & \\
\hline $25 \mathrm{R}-2,56$ & 715.7 & $"$ & & $\mathrm{x}$ & & & \\
\hline $25 \mathrm{R}-3,56$ & 717.2 & $"$ & $x$ & & & & \\
\hline $25 \mathrm{R}-3,82$ & 717.4 & $"$ & $x$ & & & & \\
\hline $25 \mathrm{R}-4,83$ & 718.9 & $"$ & $\mathrm{x}$ & & $x$ & & \\
\hline $25 R-6,78$ & 721.9 & $"$ & $x$ & & & & \\
\hline $30 R-4,62$ & 759.1 & $"$ & $x$ & & & & \\
\hline $31 \mathrm{R}-5,37$ & 769.4 & $"$ & $x$ & & & & \\
\hline $33 R-2,2$ & 783.1 & $"$ & $\hat{x}$ & & & & \\
\hline $33 \mathrm{R}-2,115$ & 784.3 & $"$ & $\mathrm{x}$ & & & & \\
\hline $33 \mathrm{R}-3,5$ & 784.6 & $"$ & $\mathrm{x}$ & & & & \\
\hline $34 \mathrm{R}-2,64$ & 793.1 & $"$ & $\mathrm{x}$ & $\mathrm{x}$ & & & \\
\hline $34 \mathrm{R}-3,15$ & 794.2 & " & $x$ & & & & \\
\hline $34 \mathrm{R}-3,89$ & 794.9 & $"$ & $x$ & & & & \\
\hline $34 \mathrm{R}-3,122$ & 795.2 & $"$ & $\mathrm{x}$ & & & & \\
\hline $34 \mathrm{R}-4,67$ & 796.2 & $"$ & $x$ & & & & \\
\hline $34 \mathrm{R}-5,26$ & 797.3 & " & $x$ & & & & \\
\hline $34 \mathrm{R}-6,4$ & 798.5 & $"$ & $x$ & & $x$ & & \\
\hline $34 \mathrm{R}-6,103$ & 799.5 & $"$ & $x$ & & & & \\
\hline $34 \mathrm{R}-7,55$ & 800.6 & $"$ & $\mathrm{x}$ & & $x$ & & $x$ \\
\hline $36 \mathrm{R}-3,109$ & 808.9 & $"$ & $\mathrm{x}$ & & & & \\
\hline $37 \mathrm{R}-2,48$ & 816.4 & " & $\mathrm{x}$ & & & & \\
\hline $37 \mathrm{R}-3,84$ & 818.2 & " & $x$ & & $x$ & & \\
\hline $37 \mathrm{R}-3,136$ & 818.8 & $"$ & $x$ & & $\mathrm{x}$ & & $x$ \\
\hline $37 \mathrm{R}-5,58$ & 821.0 & " & $x$ & & & & \\
\hline $37 \mathrm{R}-6,1$ & 821.9 & $"$ & $\mathrm{x}$ & $x$ & $x$ & & \\
\hline $41 \mathrm{R}-1,108$ & 853.5 & $"$ & $\mathrm{x}$ & $\mathrm{x}$ & $\mathrm{x}$ & & \\
\hline $41 \mathrm{R}-2,87$ & 854.8 & " & $x$ & & & & \\
\hline
\end{tabular}


APPENDIX (continued).

\begin{tabular}{|c|c|c|c|c|c|c|c|}
\hline \multirow[b]{2}{*}{ Sample No. } & \multirow[b]{2}{*}{ mbsf } & \multirow[b]{2}{*}{ Age } & \multicolumn{5}{|c|}{ Type of Sample } \\
\hline & & & Petrographic & XRD & Probe & SEM & Backscatter \\
\hline \multicolumn{8}{|l|}{ 128-799B- } \\
\hline $61 \mathrm{R}-1,100 \mathrm{~cm}$ & 1020.8 & e. Mio & $\mathrm{x}$ & & $x$ & & \\
\hline $61 R-2,135$ & 1022.9 & " & $\mathrm{x}$ & & & & \\
\hline $61 \mathrm{R}-3,15$ & 1023.0 & " & & $\mathrm{x}$ & & & \\
\hline $61 \mathrm{R}-3,131$ & 1024.1 & $"$ & $x$ & & $x$ & & \\
\hline $61 \mathrm{R}-4,138$ & 1025.7 & $"$ & $\mathrm{x}$ & & & & \\
\hline $62 \mathrm{R}-3,98$ & 1033.5 & $"$ & $x$ & & $\mathrm{x}$ & & \\
\hline $62 R-4,13$ & 1034.1 & $"$ & $x$ & & & & \\
\hline 64R-CC, 14 & 1058.3 & $"$ & $\hat{x}$ & & & & \\
\hline $65 R-2,146$ & 1061.4 & $"$ & $x$ & & $\mathrm{x}$ & & \\
\hline $67 R-1.72$ & 1078.4 & $"$ & $x$ & $\mathrm{x}$ & $\mathrm{x}$ & $\mathrm{x}$ & $\mathrm{x}$ \\
\hline $67 R-2.69$ & 1079.9 & " & & & $\mathrm{x}$ & & \\
\hline $67 R-3,59$ & 1081.3 & $"$ & $\mathrm{x}$ & $\mathrm{x}$ & & & \\
\hline
\end{tabular}

